University of Louisville

ThinkIR: The University of Louisville's Institutional Repository

Electronic Theses and Dissertations

$12-2012$

\title{
Iron acquisition by the dental pathogen aggregatibacter actinomycetemcomitans.
}

Porscha LaRai Jefferson 1986-

University of Louisville

Follow this and additional works at: https://ir.library.louisville.edu/etd

\section{Recommended Citation}

Jefferson, Porscha LaRai 1986-, "Iron acquisition by the dental pathogen aggregatibacter actinomycetemcomitans." (2012). Electronic Theses and Dissertations. Paper 681.

https://doi.org/10.18297/etd/681

This Master's Thesis is brought to you for free and open access by ThinkIR: The University of Louisville's Institutional Repository. It has been accepted for inclusion in Electronic Theses and Dissertations by an authorized administrator of ThinkIR: The University of Louisville's Institutional Repository. This title appears here courtesy of the author, who has retained all other copyrights. For more information, please contact thinkir@louisville.edu. 
IRON AQUISITION BY THE DENTAL PATHOGEN AGGREGATIBACTER ACTINOMYCETEMCOMITANS.

\author{
By \\ Porscha LaRai Jefferson \\ B.A., D.M.D, University of Louisville, 2012
}

\begin{abstract}
A Thesis
Submitted to the Faculty of the

School of Dentistry of the University of Louisville

in Partial Fulfillment of the Requirement for the Degree of
\end{abstract}

Master of Science

Department of Oral Health and Rehabilitation

University of Louisville, School of Dentistry

Louisville, Ky

December 2012 
IRON AQUISTION IN THE DENTAL PATHOGEN AGGREGATIBACTER ACTINOMYCETEMCOMITANS.

\author{
By \\ Porscha LaRai Jefferson \\ B.A., D.M.D, University of Louisville, 2012
}

A Dissertation approved on

July 25, 2012

by the following Dissertation Committee:

Donald Demuth (Dissertation Director)

David Scott (Co-mentor)

Douglas Darling 


\section{ACKNOWLEDGMENTS}

I am not the smartest, the fastest, or the best at anything but what I lack in natural ability I make up with hard work, and dedication. And it has been nothing short of hard work and dedication that has led me to accomplish my Masters degree. However due to the vast amount of work and time, dedication and perserverance were not enough. If it were not for my mentor, faculty, family, friends, and other fellow students this degree would have not been possible for me. It would still be just a dream. I would like to thank everyone involved in this accomplishment, whether it was just words of encouragement, being a listening ear, or showing me the same procedure for the $100^{\text {th }}$ time because I lost focus once again. All of your actions were appreciated and I couldn't have done this without everyone.

Dr. Demuth I don't think I can put into words how thankful I am for you. Thank you for giving me this opportunity. Thank you for maintaining your patience. I don't think I could have picked a better lab or a better mentor. You are the truly the most intelligent man I know, and if I had $1 / 100^{\text {th }}$ of your brain, I would be a very intelligent young woman. You allowed me to obtain a goal I never knew was even possible. You believed in me when I didn't believe in myself. You gave me an opportunity without question and backed me when others wouldn't. I am beyond grateful for you. Thank you so much. 
Liz, I don't even know where to begin. This Master's degree wouldn't have even been a possiblitity without you. Words can't express how much I love you and appreciate you. Not only did you take me under your wing and teach me everything that you could but you never gave up on me and never let me settle of mediocrity. I appreciate you. I appreciate you believing me, for making research fun, for not making me feel like an idiot for not remembering something that you told me 5 seconds earlier. You are an amazing scientist, mother, and friend. Your patience is out of this world. You have not only impacted my research career but you have impacted my life. I couldn't imagine doing this without you. You are such an inspiration. Thank you so much for caring about me and being an amazing friend.

Dr. Scott, and Dr. Darling thank for taking a chance on me. Thank you for pushing me while always being supportive. Thank you for this opportunity. Carlo what can I say. Thank you so much for all your help with this project. You were truly a big help in the lab and this wouldn't have been possible without you either. You sparked my interest in research and helped me obtain a goal. Thank you. Blair, Whitney, Sri, Emily, Henri, Acesion, and Dolores thank you guys for all your support. Thank you for helping me out in anyway that you could. Your hardwork and help never went unappreciated. Thank you so much. Potempa lab thank you so much for giving me the original opportunity to participate in summer research. I will never forget the smell of $P$. gingivalis. Barbara, thank you for always pushing me to do more. John Houston, thank you for always being encouraging and uplifting in this never ending battle. 
Dr. Lee Mayer thank you for always believing me and trying to make sure I did not over extend myself. You have been such an amazing inspiration to my dental and research career. You are truly a Grandpa to me and I am so thankful to have you in my life. Mrs. Jackie Williams, I couldn't imagine doing this without you. Thank you for always making sure that I had everything I needed, helping me in anyway you can. Thank you for always being there for me. But most of all thank you for always being friend to me. I appreciate it more than you will ever know.

To my Dad, Carl Jefferson, and my Mom, Tina Phillips, thank you for always supporting me and believing me. Thank you for helping me in anyway you can. Thank you for always encouraging me and always telling me that there wasn't anything that I couldn't do. I love you guys. Thank you for all your support.

To my loving husband, Colby Combs, and my daughter Audrianna Buchanan, you two are my inspiration. Everything that I do is for you two. My accomplishments would be worth nothing if it were not for you two. I love you both. Thank you so much for your support and patience in all that I do. 


\begin{abstract}
IRON AQUISITION IN THE DENTAL PATHOGEN AGGERGATIBACTER ACTINOMYCETEMCOMITANS

By

Porscha LaRai Jefferson
\end{abstract}

July 25, 2012

The dental pathogen A. actinomycetemcomitans, a Gram- negative organism, has been associated with aggressive forms of periodontitis. A. actinomycetemcomitans requires iron to grow. In the host, iron-binding proteins such as transferrin, lactoferrin, hemoglobin, and ferritin, maintain a low free-iron concentration. Microorganisms, however, have evolved complex systems to efficiently harvest iron.

Th iron acquisition systems encoded in the genome of $A$. actinomycetemcomitans are likely tailored towards the specific survival strategies needed to survive in the oral biofilm. The objectives of this project were to determine the growth of $A$. actinomycetemcomitans in different iron sources and to examine the expression of the various iron uptake systems encoded by this organism under these conditions.

A. actinomycetemcomtians was grown in chemically defined media (CDM) with or without an iron chelator (dipyridyl (DIP), and supplemented with various iron forms to determine growth. 
The growth of $A$. actinomycetemcomitans was decreased in a dose-dependent manner when cultured in CDM without exogenous ferrous sulfate supplemented with DIP (CD/DIP). Growth of A. actinomycetemcomitans was restored most efficiently when CDM/DIP was supplemented with hemin, less so with ferric citrate, and ferric chloride, and not with ferrous sulfate. Using these growth conditions, we examined the differential regulation of the numerous iron uptake systems encoded in the $A$. actinomycetemcomitans genome. 


\section{TABLE OF CONTENTS}

Acknowledgement................................................................ii

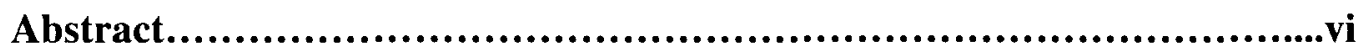

Table of Contents...........................................................viii

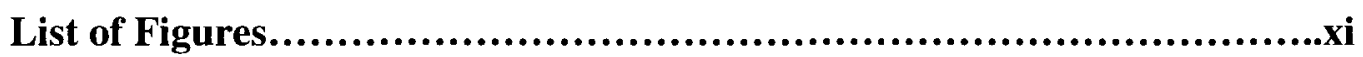

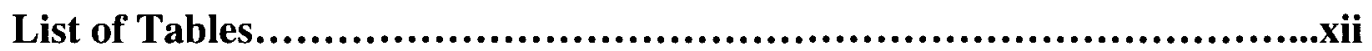

Chapter 1: Introduction

Periodontal Disease....................................................1

Microbial Induction of Periodontal Disease...........................5

Aggregatibacter actinomycetemcomitans..................................8

Necessity of Iron .......................................................11

Chapter 2: Materials and Methods

Bacterial strains and culture conditions................................14

Achievement of an Iron Limited Enviroment............................16

Achievement of an Iron Chelated Environment............................21

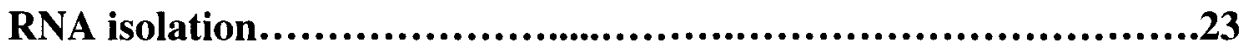


cDNA synthesis and $q P C R$ for iron acquistion gene expression......24

Chapter 3: Expression of Iron Acquistion Genes in Aggregatibacter Actinomycetemcomitans.

Introduction........................................................25

Results..............................................................26

A. actinomycetemcomitans is capable of growing in an iron limited environment..........................................27

Growth of A. actinomycetemcomitans is limited in an iron chelated

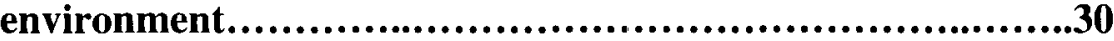

Growth of $A$. actinomycetemcomitans utilizing different iron sources............................................................33

Differential expression of iron-uptake genes under an iron

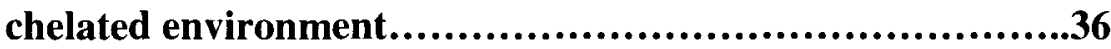

Discussion...........................................................40

Chapter 4: Summary and Future Directions 
References.....................................................................45

Curriculum vitae.............................................................50 


\section{LIST OF TABLES}

\section{Chapter 1}

Table 1: $\quad$ Iron Uptake Operons in A. actinomycetemcomitans...............13

\section{Chapter 2}

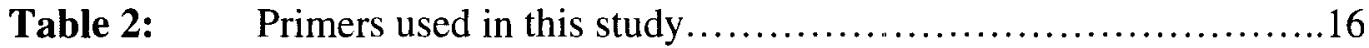

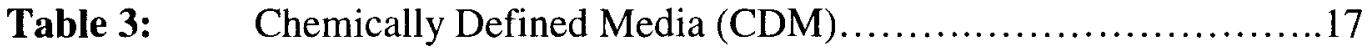

\section{Chapter 3}

Table 4a: $\quad$ Expression of afuA 1642 (iron (III) ABC transporter)............36

Table 4b: Expression of afuA 0696 (periplasmic iron-compound-binding protein).................................................37

Table 4c: $\quad$ Expression of hgpA 0762 (hemoglobin binding protein A) .......37

Table 4d: $\quad$ Expression of $f e c B 0795$ (iron (III) dicitrate-binding

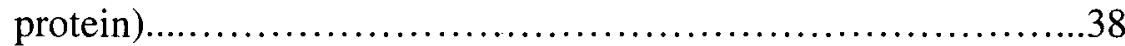

Table 4e: $\quad$ Expression of $f t n A 2120$ (non heme ferritin)................... 38 


\section{LIST OF FIGURES}

\section{Chapter 1}

Figure 1: Anatomy of the periodontium................................6

Figure 2: $\quad$ Characteristics of clinical isolates of $A$. actinomycetemcomitans. 10

\section{Chapter 2}

Figure 3: Achievement of an iron limited and iron chelated environment....23

\section{Chapter 3}

Figure 4: $\quad$ Growth of $A$. actinomycetemcomitans in an iron limited environment.............................................28

Figure 5a: Achievement of an iron chelated environment with $100 \mathrm{uM}$

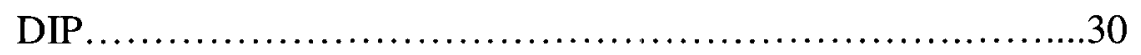

Figure 5b: Achievement of an iron chelated environment with $150 \mathrm{uM}$ DIP..........................................................

Figure 5c: Achievment of an iron chelated environment with $200 \mathrm{uM}$

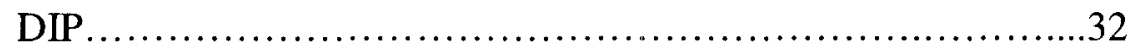

Figure 6: Growth of A. actinomycetemcomitans utilizing different iron sources. 


\section{INTRODUCTION}

\section{Periodontal Disease}

Periodontal disease is a chronic progressive disease that affects various structures of the periodontal tissues including the alveolar bone and periodontal ligament. Periodontal disease has been divided into two separate categories: Gingivitis and Periodontitis. Both diseases are inflammatory conditions that are encompassed in the term periodontal disease, however the affects of both diseases are quite different. Gingivitis, the initial stage of periodontal disease, is an inflammation of the gingival tissue characterized by swelling, redness, and bleeding upon probing of the gingiva (3). Although gingivitis is reversible following proper oral hygiene, if left untreated, it can progress into the more severe, chronic inflammatory condition, periodontitis. Periodontitis always develops from gingivitis however not all gingivitis will progress into periodontitis.

Periodontitis is defined as a condition in which there is an inflammatory reaction that occurs in the periodontium resulting in the destruction of the supporting soft tissues surrounding the teeth, loss of gingivial fibers of the periodontal ligament, and resorption of the alveolar bone. Periodontitis has also been further categorized into mild, moderate, and severe periodontitis based on the patients clinical attachement loss $(39,40)$. Mild periodontits presents with 1-2 $\mathrm{mm}$ of attachment loss, moderate periodontitis 
presents with 3-4 mm of attachment loss, and severe periodontitis displays attachment loss greater than $4 \mathrm{~mm}$. Periodontitis is even further divided into chronic or acute forms and generalized (presenting in greater than $30 \%$ of the oral cavity) or localized (less than $30 \%$ of the oral cavity is involved).

Due to the progressive nature of this condition, if periodontitis is left untreated, loosening and/or tooth loss is usually the result. Due to the destructive nature of periodontal disease, it has been a frequent interest in many research projects. It has been concluded that periodontal disease is the clinical result of a complex interaction between the host and plaque bacteria. Destruction of periodontal supporting tissues happens as a response to very intricate host-parasite interactions. The net result of this host-parasite interaction, which in an unpredictable moment, accumulate and exceed the threshold of tissue integrity thus causing tissue destruction and ultimate bone loss.

Periodontal disease is the most prevalent of bone diseases in humans and has long been implicated as a risk factor in impairment of oral functions and tooth loss. $10-15 \%$ of adults that have periodontal disease have it severely enough that it results in tooth loss, ultimately leading to mastication malfunction and ageusia. While periodontal disease is prevalent worldwide, it has had a significant impact on the United States population (9, $18,52)$. Brown et al estimate that about $21.8 \%$ of adults ( 22.6 million $)$ exhibit signs of mild periodontitis, $9.5 \%$ (9.9 million) display signs of moderate periodontitis, and about $3.1 \%$ (about 3.2 million) exhibit signs of advanced periodontitis (9). The total amount expended for periodontal preventive procedures as well as the treatment of periodontal diseases in the U.S. was $\$ 14.3$ billion in 1999 (9). Undoubtedly, innovative methods for 
the prevention and treatment of periodontal disease would have a major impact on healthcare costs.

Past research has suggested periodontal disease can be complicated by certain systemic diseases, however more recently, studies suggest that the reverse may also be true $(13,28,29,32,44,46,50)$. Current research, however controversial, proposes that periodontal disease has important systemic implications, and can influence other diseases such as cardiovascular disease $(28,29,36,39)$, pulmonary disease $(44,55)$ diabetes $(23$, $32,50)$, and adverse pregnancy outcomes $(11,46,47)$. Thus, a better understanding of the factors that contribute to periodontal disease can be used to develop measures to improve not only oral health of the patient, but also overall health of individuals.

The onset and progression of periodontal disease is associated with several risk factors, including but not limited to gender, age, socio-economic status, nutrition, stress, genetic makeup, and tobacco smoke. Though there are several risk factors, tobacco smoke has been considered one of the most important risk factors associated with periodontal disease (54). It is theorized that there is a positive correlation between increased tobacco usage in the population and increased numbers of periodontal infections $(33,52)$. A dose-dependent correlation has been demonstrated between the frequency of an individual smoker and the severity of the deteriorating periodontal health of that individual (6). Smokers are extremely more susceptible to periodontitis, with increased alveolar bone resorption (24), attachment loss, percentage of oral sites with significant attachment loss (25), tooth mobility, and tooth loss (42) than non smokers. Additionally, patients who smoke are more often refractory to treatment than nonsmokers (49). Despite conflicting data that tobacco smoke may not influence the sub- 
gingival microflora $(22,10)$, recent data strongly indicates that tobacco-induced susceptibility to periodontitis is correlated with populational shifts in the microbial composition of the oral biofilm $(15,19,26)$. For example, Umeda et al showed that there is an increased risk of Treponema denticola inhabiting the oral cavity of smokers (61); while Zambon et al reported a higher prevalence of Aggregatibacter actinomycetemcomitans, Tannerella forsythia and Porphyromonas gingivalis in smokers (66).

While all of these factors play a role in the progression and severity of the disease, there is clear evidence that the inflammatory response in the periodontum is initiated against the resident microbial biofilm within the subgingival pocket (1). It is this inflammatory reaction caused by the host innate immune response to the bacterial pathogen that dictates the severity and progression of the periondontal infection (5).

The oral biofilm consists of several hundred bacterial species, but periodontal disease is often associated with a progressive succession of the predominant bacterial species in dental plaque from Gram-positive to Gram-negative $(1,4)$. In order for bacteria to colonize and persist in a host, bacterial pathogens must be able to counteract the innate and adaptive immune system of the host. Bacteria are able to evade the host immune system by maintaining a plethora of virulence factors. Many bacteria produce numerous virulence factors that have been well-characterized, including adherence proteins, cytotoxic factors, biofilm polysaccharides, chemotactic inhibitor, collagenases, LPS, and toxins to counteract the host immune system. It is these different bacterial behaviors and the resulting immune response to these pathogens that combine to promote inflammatory tissue destruction in periodontitis (5). The production by various proinflammatory 
cytokines (i.e. IL-1B, IL-6, TNF $\alpha$, IL-8, and RANKL) in response to specific Gramnegative bacteria within the oral cavity leads to the activation of osteoclasts (37). Activation of the bone-resorbing osteoclasts eventually results in bone resorption and alveolar bone loss—clinical symptoms of periodontitis $(41,45,51)$.

\section{Microbial Induction of Periodontal Disease}

Dental plaque is the single most important risk factor associated with the onset and progression of periodontal disease (1). The formation of dental plaque begins with adsorption of early colonizing bacteria onto an acquired pellicle, a layer of salivary proteins that is mainly composed of glycoproteins that forms shortly after a dental cleaning or tooth eruption. Once an acquired pellicle is formed, early colonizers are able to manipulate the environment in order for other bacteria to be able to colonize and adhere, thus forming dental plaque. It is this dental plaque that initiates the host inflammatory reaction (5). 
A.

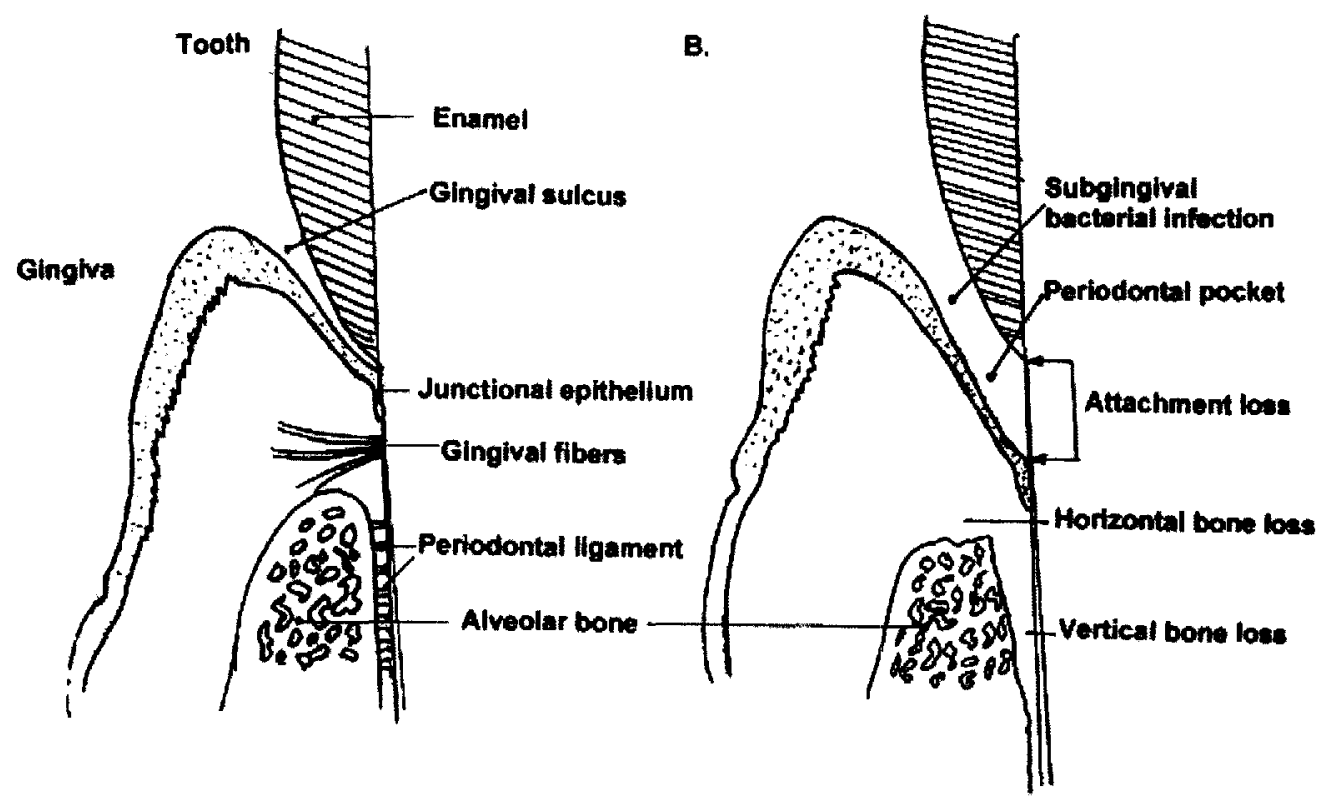

Figure 1. Anatomy of the periodontium (as reviewed by Baker, P.J. (12)).

A) In health, gingival fibers connect the gingival soft tissue to the root of the tooth, and the alveolar bone and cementum are connected by periodontal ligament fibers. B) In periodontal disease, subgingival infection by Gram-negative bacteria results in soft tissue damage, producing attachment loss and deepening the sulcus into the periodontal pocket. Alveolar bone resorption moves the bone surface away from the tooth root (vertical bone loss) and reduces the height of the alveolar bone crest (horizontal bone loss). Copyright permission to reproduce figure granted by Elsevier and (5). 
As mentioned previously, bacteria are able to adhere to the acquired pellicle on hard tissue to form a biofilm. The ability of bacteria to adhere tightly to underlying substrata impedes the efficient removal of biofilms by physical or chemical means. In the oral cavity, biofilms form on the surfaces of both hard and soft tissues, and the development of the biofilm depends on interactions between both bacterial cell-surface adhesions and host receptors and bacteria-bacteria interactions (12). Without the ability to adhere to surfaces in the oral cavity, bacteria are swallowed with the saliva and enter the digestive tract, where they may not survive.

The last stage of bacterial colonization in the oral cavity involves late colonizers, whose presence is often associated with periodontal disease progression. A hallmark of inflammatory periodontal disease is the increased subgingival colonization by several Gram-negative species, including A. actinomycetemcomitans, Prevotella intermedia, Campylobacter rectus, and a group of three other bacteria designated 'the red complex' bacteria (T. denticola, $T$. forsynthia, and $P$. gingivalis) (40). It is the bacteria previously mentioned that are considered the late colonizers or the anaerobic bacteria that cause this inflammatory reaction in the gingival tissues. The red complex is a group of microorganisms that are most intimately associated with adult periodontal disease. $A$. actinomycetemcomitans, another late colonizer, is associated with an aggressive form of periodontitis primarily found in juveniles, however this bacterial speices can also be found in chronic periodontitis as well (58). 


\section{Aggregatibacter actinomycetemcomitans}

A. actinomycetemcomitans (formerly Actinobacillus actinomycetemcomitans) is a small, fastidious, $\mathrm{CO}_{2}$-requiring coccobacillus (34). It is a capnophilic, facultative anaerobic Gram-negative bacterium that belongs to the family Pasteurellaceae (34). A. actinomycetemcomitans was initially isolated from actinomycotic oral lesions along with Actinomyces israelii, leading to its species name (30). A. actinomycetemcomitans was first isolated in 1912 (38), however it was never recognized as a member of the oral microbial environment until 1975 (35). A. actinomycetemcomitans has been associated with several systemic infections including chronic periodontitis, but the pathogen is most known for its strong association with localized aggressive periodontitis, an extremely destructive form of periodontal disease that is most common in adolescents and young adults (58). The fact that $A$. actinomycetemcomitans has also been recovered from subgingival microflora of periodontally healthy patients suggest that $A$. actinomycetemcomitans may also represent an opportunistic pathogen. Due to $A$. actinomycetemcomitans strong association with localized aggressive periodontitis, most studies of $A$. actinomycetemcomitans have focused on its role in this disease. If the disease is left untreated, localized aggressive periodontitis results in rapid destruction of the alveolar bone and all supporting structures ultimately causing tooth loss. The disease specifically targets the mandibular incisors and first molars (65).

A. actinomycetemcomitans, like other bacterial pathogens, utilizes a plethora of virulence factors to cause disease and evade the host immune response. $A$. actinomycetemcomitans produces numerous virulence factors that have been wellcharacterized, including adherence proteins, cytotoxic factors, biofilm polysaccharides, 
chemotactic inhibitor, collagenases, LPS, and toxins. There is also strong evidence that leukotoxin (LtxA), a 116-kDa protein that belongs to the repeats-in-toxin (RTX) family of pore forming toxins, expression affects disease progression $(8,31)$. Studies have shown that the target of LtxA is quite specific, which is unusual among RTX toxins, killing only polymorphonuclear leukocytes, monocytes and T-cells, all cells responsible for the innate immune response, in humans, apes, and Old World monkeys (60). Previous studies have also demonstrated the ability of A. actinomycetemcomitans to bind and invade epithelial (43) and endothelial cells (56), which may be an important mechanism for evading the host immune system and disseminating beyond the initial site of infection (17). Furthermore, fresh clinical isolates of A. actinomycetemcomitans express fimbriae (Figure 2), which allow them to form tenacious biofilms on a variety of solid surfaces, such as hydroxyapatite, glass, and plastic (53). Fimbriae expression may be important in biofilm pathogenesis in vivo, however it is not the sole determinant in biofilm formation, as isogenic smooth strains are capable of forming biofilms (57). However fimbriae are thought to enable A. actinomycetemcomitans to colonize the tooth surface, persist in the oral cavity, and initiate infection in the presence of salivary flow, thus classifying them as a virulence factor. 


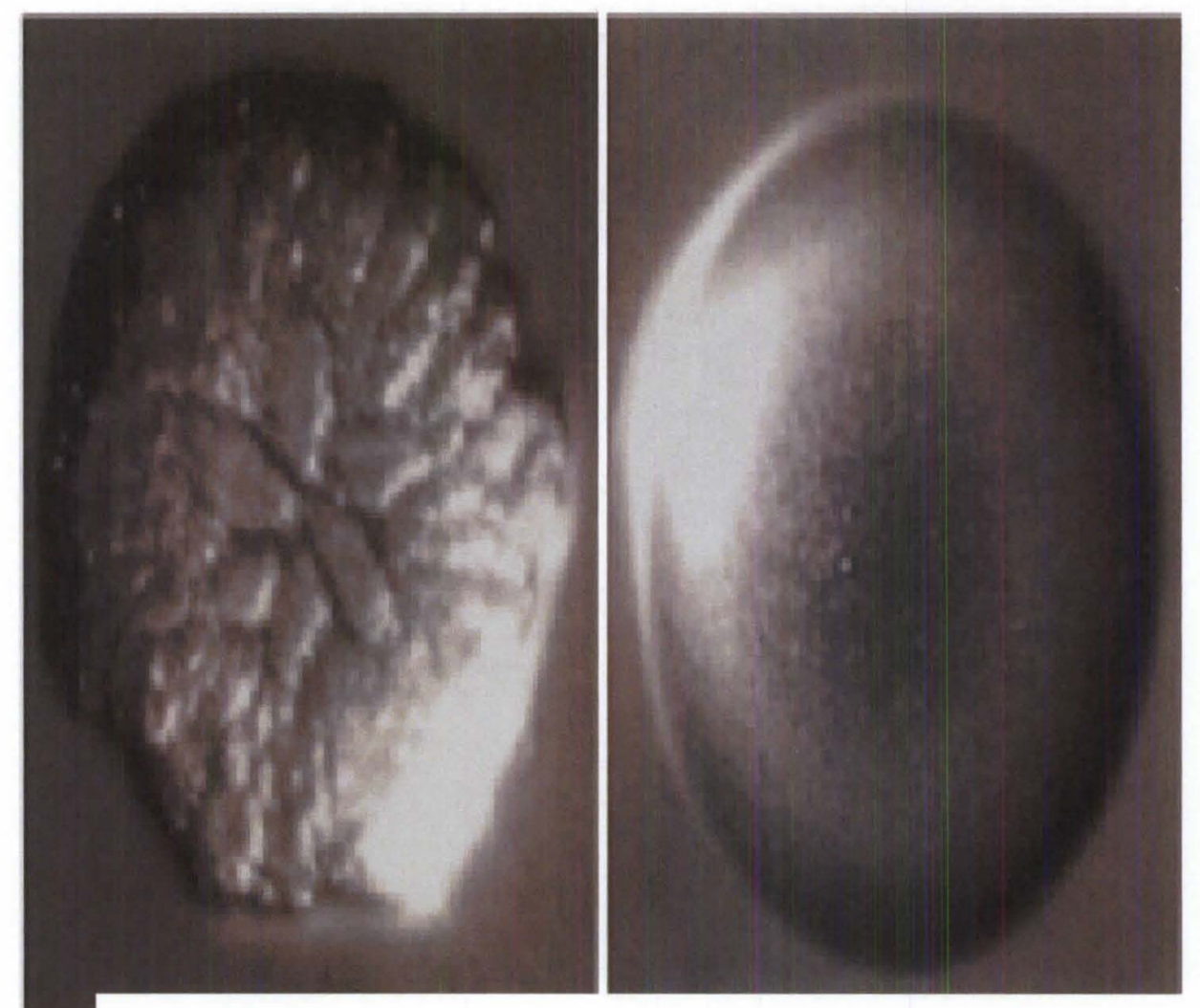

Figure 2. Characteristics of clinical isolates of $A$. actinomycetemcomitans

(16). A) When A. actinomycetemcomitans is initially isolated from the oral cavity and cultured on solid medium, it grows as a 'rough' colony with a characteristic star-like structure in the center. B) As the bacterium is passaged in liquid broth, it loses its ability to express fimbriae due to a spontaneous mutation in the flp promoter region, and the broth becomes turbid with the growth of isogenic non-adherent variants. When plated on solid medium, these variants form large, smooth colonies (16). Copyright permission to reproduce figure granted by Society for General Microbiology and (16). 


\section{Necessity of Iron}

Iron is the most abundant metal in nature, and as such, plays a major role in the life processes of all organisms (62). Iron is the central atom of the heme group in hemoglobin, which is necessary for oxygen transport in blood. Iron is also present in myogloboin which allows oxygen to diffuse through muscle cell), cytochromes (proteins involved in the electron transport chain), proteins involved with DNA synthesis and cell divison. Furthermore, iron is used to help produce the connective tissues in the human body, it is incorporated in the production of neurotransmitters, as well as playing an integral role in the maintenance of human immune system. Due to the fact that iron plays such a integral role in life processes it is tightly regulated. Too little iron can lead to iron deficiency anemia and present with symptoms of constant fatigue, palor, and severe weakness. Too much iron is known as hemochromatosis and can present as abdominal pain, fatigue, and generalized darkening of the skin.

The paucity of free iron in mucous membranes, tissues, or body fluids acts as a host defense mechanism against bacterial infections by creating a bacteriostatic environment, because iron is an essential nutrient for all life (22). Host iron binding proteins such as transferrin, lactoferrin, hemoglobin, ferritin all act collectively to maintain a low free iron concentration, thus inhibiting bacterial growth (63). As mentioned before all organisms require iron to survive. A critical component of bacterial virulence is the ability to obtain iron from their host. Several bacteria have evolved ironsequestering mechanisms such as the secretion of siderophores, which compete with host 
iron binding molecules for iron. Previous research has shown that $A$. actinomycetemcomitans is not capable of binding transferrin $(22,64)$. In addition, this dental pathogen is not known to excrete siderophores (64). However, it has been shown that A. actinomycetemcomitans is capable of binding both lactoferrin and hemoglobin (2, 21), two iron-containing compounds that serve as iron sources for other bacteria (48). The exact sources that A. actinomycetemcomitans utilizes in the oral cavity are not known.

Research to date has shown that $A$. actinomycetemcomitans has at least 15 iron aquistion genes encoded in its genome (54). The amount of A. actinomycetemcomitans' genome involved in iron aquistion suggests the importance of iron availability to the survival of this organism. With all of this capability that A. actinomycetemcomitans has to obtain iron, there must be some discression or priority in the specific type of iron that A. actinomycetemcomitans prefers to utilize. The iron acquisition systems encoded in the genome of $A$. actinomycetemcomitans are tailored towards the specific survival strategies needed to survive in the oral biofilm. Due to A. actinomycetemcomitans genome and the the fact that A. actinomycetemcomitans is a faculatative anaerobe, $A$. actinomycetemcomitans is expected to be able to utilize inorganic and organic as well as ferric and ferrous iron sources both in planktonic culture and biofilms. The most common iron transport systems utilized by bacteria seem to be the ferric iron transport complexes such as $\mathrm{ABC}$ transporters. However other bacteria such as $H$. pylori, E coli, $P$. ginigivalis and $V$. cholera also employ ferrous iron transport through Feo (Ferrous Iron Transport) systems. Due to relatively soluble nature of ferrous iron $(0.1 \mathrm{M}$ for $\mathrm{Fe} 2+\mathrm{cf} 10 \wedge-18 \mathrm{M}$ for $\mathrm{Fe} 3+$ at $\mathrm{pH} 7$ ), it would seem that ferrous iron would be the preferred iron source for 
most bacteria (68). However only under anaerobic conditions, or low $\mathrm{pH}$ environments does ferrous iron transport seem predominant. This fact lead us to believe that $A$. actinomycetemcomitans is able utilize ferrous iron as well as ferric iron transport in the oral cavity $(68,69,70)$. Our hypothesis is that A. actinomycetemcomitans primarily utilizes ferric iron and hemin as iron sources in the oral biofilm due to the nature of $A$. actinomycetemcomitans genome. In this study, we investigate the planktonic growth of $A$. actinomycetemcomitans in an iron-limited and iron-chelated environment as well as analyze the ability of $A$. actinomycetemcomitans to grow in an iron-chelated environment supplemented with different iron sources and investigate what particular iron aquistion genes are being upregulated in each particular iron environment. 


\begin{tabular}{|c|c|c|}
\hline Gene Name & Gene ID & Definition \\
\hline hmsHF & $\begin{array}{c}\text { AA00490,0 } \\
0491\end{array}$ & hemin transport and storage \\
\hline afuABC & $\begin{array}{c}\text { AA00696-0 } \\
0700 \\
\end{array}$ & iron(III) $A B C$ transporter \\
\hline hgpA & AA00762 & hemoglobin binding protein $\mathrm{A}$ \\
\hline fecBCDE & $\begin{array}{r}\text { AA00795-0 } \\
0799\end{array}$ & iron(III) dicitrate transporter \\
\hline $\begin{array}{l}\text { hitABC } \\
\text { (afuABC) }\end{array}$ & $\begin{array}{c}\text { AA01048-0 } \\
1051\end{array}$ & iron (III) ABC transporter \\
\hline afuABC & $\begin{array}{c}\text { AA01642-0 } \\
1645\end{array}$ & iron(III) $A B C$ transporter \\
\hline fatBDCE & $\begin{array}{r}\text { AA01824-0 } \\
1827\end{array}$ & enterochelin transporter \\
\hline$f \operatorname{tn} A B$ & $\begin{array}{r}\text { AA02120,0 } \\
2121\end{array}$ & nonheme ferritin \\
\hline hemU, fecD & $\begin{array}{r}\text { AA02144,0 } \\
2145\end{array}$ & iron(III) ABC transporter \\
\hline sidABCD & $\begin{array}{c}\text { AA02151-0 } \\
2154 \\
\end{array}$ & ferric enterobactin transporter \\
\hline tbpa & AA02201 & transferrin-binding protein \\
\hline fecB & AA02380 & $\begin{array}{l}\text { ferric hydroxamate (chelatin) periplasmic-binding } \\
\text { protein }\end{array}$ \\
\hline fur & AA02516 & Fur, ferric uptake regulator \\
\hline AfeABCD & $\begin{array}{c}\text { AA02549-0 } \\
2552\end{array}$ & iron (chelated) ABC transporter \\
\hline hasR & AA02782 & Outer membrane hemophore receptor \\
\hline
\end{tabular}

Table 1. Iron Uptake Operons in A. actinomycetemcomitans. Iron acquisition operons encoded in A. actinomycetemcomitans genome (54). There is a redundancy of ferric iron transporters (ABC transporters), hemin and hemoglobin transporters. $A$. actinomycetemcomitans even seems to be able to utilize sideophore like molecules secreted from other bacteria through utilization of it's enterochelin transport system. 


\section{CHAPTER TWO:}

\section{MATERIALS AND METHODS}

Bacterial strains and culture conditions. A. actinomycetemcomitans bacterial strain employed in this study was A. actiomycetemcomitans 652. A. actinomycetemcomitans 652 is an afimbriated, smooth colony morphotype strain and was grown at $37^{\circ} \mathrm{C}$ under microaerophilic conditions in Chemically Defined Media (CDM; Sigma-Aldrich, St. Louis, MO) and CDM supplemented with 150 uM of dipyridyl (DIP; Sigma-Aldrich, St. Louis, MO) per liter. Ferric Chloride, Ferric Citrate, Ferrous Sulfate, Hemin (Sigma-Aldrich, St. Louis, MO) were added to CDM with DIP at a $250 \mathrm{uM}$ concentration per liter. 
Table 2. Primers* used in this study.

$\begin{array}{cccc}\text { Primers } & \text { Primer Sequence (5' - 3') } & \text { Target Gene } & \text { Size (kbp) } \\ & & & \\ \text { 5' } 00696 & \text { CGGATTACTCGCCTCACAAGCG } & \text { afuA 00696 } & 0.318 \\ \text { 3' } 0696 & \text { CCTTTGGTTTTTGCCGGATCGC } & \text { afuA } 00696 & 0.318 \\ \text { 5' } 00795 & \text { GCGCAGAAAATCGGTGATGTCGTGG } & \text { fecB 00795 } & 0.317 \\ \text { 3' } 00795 & \text { GCGATACTTTCCTGACGATAGTGTGC } & \text { fecB 00795 } & 0.317 \\ \text { 5' 5S rRNA } & \text { GCGGGGATCCTGGCGGTGACCTACT } & \text { 5S-2-rRNA } & 0.089 \\ \text { 3' 5S rRNA } & \text { GCGATCTAGACCACCTGAAACCATACC } & \text { 5S-2-rRNA } & 0.089 \\ \text { 5' } 01642 & \text { CGCAGGCGGATTTTTGGTATGGCG } & \text { afuA 01642 } & 0.191 \\ \text { 3' } 01642 & \text { CCGGCAGTTGAACCTCGCCTTTGTA } & \text { afuA 01642 } & 0.191 \\ \text { 5' AA02120 } & \text { GCAAGGTTATGAAGGTGCTGCGGC } & \text { ftnA/rsgA 02120 } & 0.351 \\ \text { 3' AA02120 } & \text { GCAGTGCCGCTTTTGCCAAGAAGTTTA } & \text { ftnA/rsgA 02120 } & 0.351 \\ \text { 5' AA00762 } & \text { CCATGGAATTGAGACAACAAGCAACGTTAG } & \text { hgpA AA00762 } & 0.263 \\ \text { 3' AA00762 } & \text { TCTAGATAGTCCAATTCCTGCGGTAAA } & \text { hgpA AA00762 } & 0.263\end{array}$


Achievement of an Iron Limited Environment. A. actinomycetemcomitans was grown in a chemically defined media (CDM) in order to regulate the amount and type of iron that the bacteria could use for growth. A. actinomycetemcomitans was grown in CDM that contained FeS04 (CDM regular), and was then passaged into CDM that lacked an iron source (FeSO4), creating an iron limited environment.

\section{Chemically Defined Media (CDM)}

\begin{tabular}{|c|c|}
\hline Amino Acids & $1 \mathrm{~L}$ of $20 \times(\mathrm{g})$ \\
\hline L-Glutamic Acid $\mathrm{HCl}$ & $27.2 \mathrm{mM}$ \\
\hline Glycine & $26.6 \mathrm{mM}$ \\
\hline L-Threonine & $16.79 \mathrm{mM}$ \\
\hline L-Serine & $19.03 \mathrm{mM}$ \\
\hline L-Lysine $\mathrm{HCl}$ & $10.95 \mathrm{mM}$ \\
\hline L-Arginine $\mathrm{HCl}$ & $11.49 \mathrm{mM}$ \\
\hline L-Histidine $\mathrm{HCl} \mathrm{H} 20$ & $14.09 \mathrm{mM}$ \\
\hline L-Glutamine & $8.38 \mathrm{mM}$ \\
\hline L-Asparagine $\mathrm{H} 20$ & $15.12 \mathrm{mM}$ \\
\hline L-Proline & $13.23 \mathrm{mM}$ \\
\hline L-Asparatic Acid & $15.03 \mathrm{mM}$ \\
\hline L-Ornithine $\mathrm{HCl}$ & $2.37 \mathrm{mM}$ \\
\hline L-Hydoxyproline & $3.05 \mathrm{mM}$ \\
\hline
\end{tabular}




\begin{tabular}{|c|c|}
\hline Amino acids (Hydrophobic) & 1L of 20x (g) \\
\hline L-Alanine & $22.45 \mathrm{mM}$ \\
\hline D-Alanine & $22.45 \mathrm{mM}$ \\
\hline L-Leuicine & $15.25 \mathrm{mM}$ \\
\hline L-Valine & $17.07 \mathrm{mM}$ \\
\hline L-Tryptophan & $9.79 \mathrm{mM}$ \\
\hline L-Methionine & $13.40 \mathrm{mM}$ \\
\hline L-Isoleucine & $15.25 \mathrm{mM}$ \\
\hline L-Phenylalanine & $12.11 \mathrm{mM}$ \\
\hline L-Tyrosine & $2.21 \mathrm{mM}$ \\
\hline L-Cystine & $416.2 \mu \mathrm{M}$ \\
\hline
\end{tabular}

\begin{tabular}{|c|c|}
\hline Purines/Pyrimidines & $1 \mathrm{~L}$ of $20 \mathrm{x}(\mathrm{g})$ \\
\hline Adenine & $1.85 \mathrm{mM}$ \\
\hline Guanine & $1.32 \mathrm{mM}$ \\
\hline Cytosine $\mathrm{HCl}$ & $2.43 \mathrm{mM}$ \\
\hline Thymine & $1.59 \mathrm{mM}$ \\
\hline Xanthine & $1.31 \mathrm{mM}$ \\
\hline Hypoxanthine & $1.47 \mathrm{mM}$ \\
\hline Uracil & $1.78 \mathrm{mM}$ \\
\hline
\end{tabular}




\begin{tabular}{|c|c|}
\hline Inorganic Salts & 1L of $20 \mathrm{x}(\mathrm{g})$ \\
\hline $\mathrm{MnSO} 4$ & $830.8 \mu \mathrm{M}$ \\
\hline $\mathrm{NaCl}$ & $34.2 \mathrm{mM}$ \\
\hline K2HPO4 & $22.9 \mathrm{mM}$ \\
\hline KH2PO4 & $146.9 \mathrm{mM}$ \\
\hline KNO3 & $19.78 \mathrm{mM}$ \\
\hline
\end{tabular}

\begin{tabular}{|c|c|}
\hline Inorganic Salts & $1 \mathrm{~L}$ of $20 \mathrm{X}(\mathrm{g})$ \\
\hline KI & $12.05 \mu \mathrm{M}$ \\
\hline CuSO4 5H20 & $5.206 \mu \mathrm{M}$ \\
\hline Boric Acid & $161.7 \mu \mathrm{M}$ \\
\hline ZnS04 7H2O & $56.8 \mu \mathrm{M}$ \\
\hline Sodium & $48.6 \mu \mathrm{M}$ \\
molybdate & \\
\hline
\end{tabular}

\begin{tabular}{|c|c|}
\hline Vitamins/Factors & 1L of $1000 \mathrm{x}(\mathrm{g})$ \\
\hline Choline chloride & $358.1 \mathrm{mM}$ \\
\hline Beta-alanine & $112.2 \mathrm{mM}$ \\
\hline Pyridoxal & $4.04 \mathrm{mM}$ \\
\hline Pyridoxine $\mathrm{HCl}$ & $5.91 \mathrm{mM}$ \\
\hline Pyridoxamine diHCl & $4.15 \mathrm{mM}$ \\
\hline
\end{tabular}




\begin{tabular}{|c|c|}
\hline Spermidine $\mathrm{HCl}$ & $6.88 \mathrm{mM}$ \\
\hline Nicotinic acid & $8.12 \mathrm{mM}$ \\
\hline Nicotinaminde & $8.19 \mathrm{mM}$ \\
\hline Calcium pantothenate & $4.56 \mathrm{mM}$ \\
\hline Spermine tetraHCl & $2.87 \mathrm{mM}$ \\
\hline Thiamine $\mathrm{HCl}$ & $3.32 \mathrm{mM}$ \\
\hline Myo-Inositol & $55.5 \mathrm{mM}$ \\
\hline Nicotinamide adenine & $1.51 \mathrm{mM}$ \\
\hline dinucleotide & \\
\hline p- Aminobenzoic acid & $729.2 \mu \mathrm{M}$ \\
\hline Vitamin B12 & $7.38 \mu \mathrm{M}$ \\
\hline
\end{tabular}

\begin{tabular}{|l|c|}
\hline & 1L of $20 \mathrm{x}$ \\
\hline $\mathrm{NaHCO} 3$ & $23.8 \mathrm{mM}$ \\
\hline
\end{tabular}

\begin{tabular}{|l|c|}
\hline & $1 \mathrm{~L}$ of $20 \mathrm{x}$ \\
\hline L- Cysteine $\mathrm{HCl}$ & $10.7 \mathrm{mM}$ \\
\hline
\end{tabular}

\begin{tabular}{|c|c|}
\hline & $1 \mathrm{~L}$ of $1 \mathrm{x}(\mathrm{g})$ \\
\hline MgSO4 7H20 & $28.4 \mu \mathrm{M}$ \\
\hline
\end{tabular}




\begin{tabular}{|c|c|}
\hline & 1L of $1 \mathrm{X}(\mathrm{g})$ \\
\hline FeS04 7H20 & $17.9 \mathrm{mM}$ \\
\hline
\end{tabular}

\begin{tabular}{|c|c|}
\hline & 1L of $1 \times(\mathrm{mg})$ \\
\hline $\mathrm{CaCl} 22 \mathrm{H} 20$ & $680.2 \mu \mathrm{M}$ \\
\hline
\end{tabular}

\begin{tabular}{|c|c|}
\hline & $1 \mathrm{~L}$ of $1 \mathrm{x}$ \\
\hline Pimelic acid & $624.2 \mathrm{nM}$ \\
\hline D- Biotin & $409.3 \mathrm{nM}$ \\
\hline DL-6,8-thioctic & $484.6 \mathrm{nM}$ \\
\hline Folic acid & $2.265 \mu \mathrm{M}$ \\
\hline
\end{tabular}

\begin{tabular}{|l|c|}
\hline & 1L of $1 \mathrm{X}(\mathrm{mg})$ \\
\hline Riboflavin & $2.66 \mu \mathrm{M}$ \\
\hline
\end{tabular}

Table 6. A. actinomycetemcomitans Chemically Defined Media. All chemicals used were from Sigma-Aldrich, St. Louis, MO. 


\section{Achievement of an Iron Chelated Environment. $A$.}

Actinomycetemcomitans growth was achieved by passaging the bacteria in an iron limited environment (a media in which no exogenous iron source was added) and an iron chelated environment (a media in which a chelator was added). On Day 1, $A$.

actinomycetemcomitans strain 652 was inoculated into regular CDM from a frozen stock. This culture was incubated at $37^{\circ} \mathrm{C}$ overnight under microaerophilic conditions. On Day 2 , the bacteria from the overnight culture of regular CDM was inoculated into CDM with no iron plus $100 \mathrm{uM}, 150 \mathrm{uM}$ or $200 \mathrm{uM}$ of dipyridyl (DIP) to achieve a $1^{\text {st }}$ passage in an iron chelated environment. This $1^{\text {st }}$ passage was incubated at $37^{\circ} \mathrm{C}$ overnight under microaerophilic conditions. On Day 3, the bacteria from the overnight culture of CDM no iron $1^{\text {st }}$ passage plus $100 \mathrm{uM}, 150 \mathrm{uM}$, or $200 \mathrm{uM}$ of DIP was inoculated into fresh media of CDM no iron plus $100 \mathrm{uM}, 150 \mathrm{uM}$, or $200 \mathrm{uM}$ of DIP to achieve a $2^{\text {nd }}$ passage in an iron chelated environment. CDM no iron is an iron-limited environment. CDM no iron supplemented with DIP (iron chelator) is an iron-chelated environment. Growth of $A$. actinomycetemcomitans was accessed by measuring optical densities of the bacteria at $600 \mathrm{nM}$ utilizing spectrophotometer. Figure 3 shows how this was accomplished. 


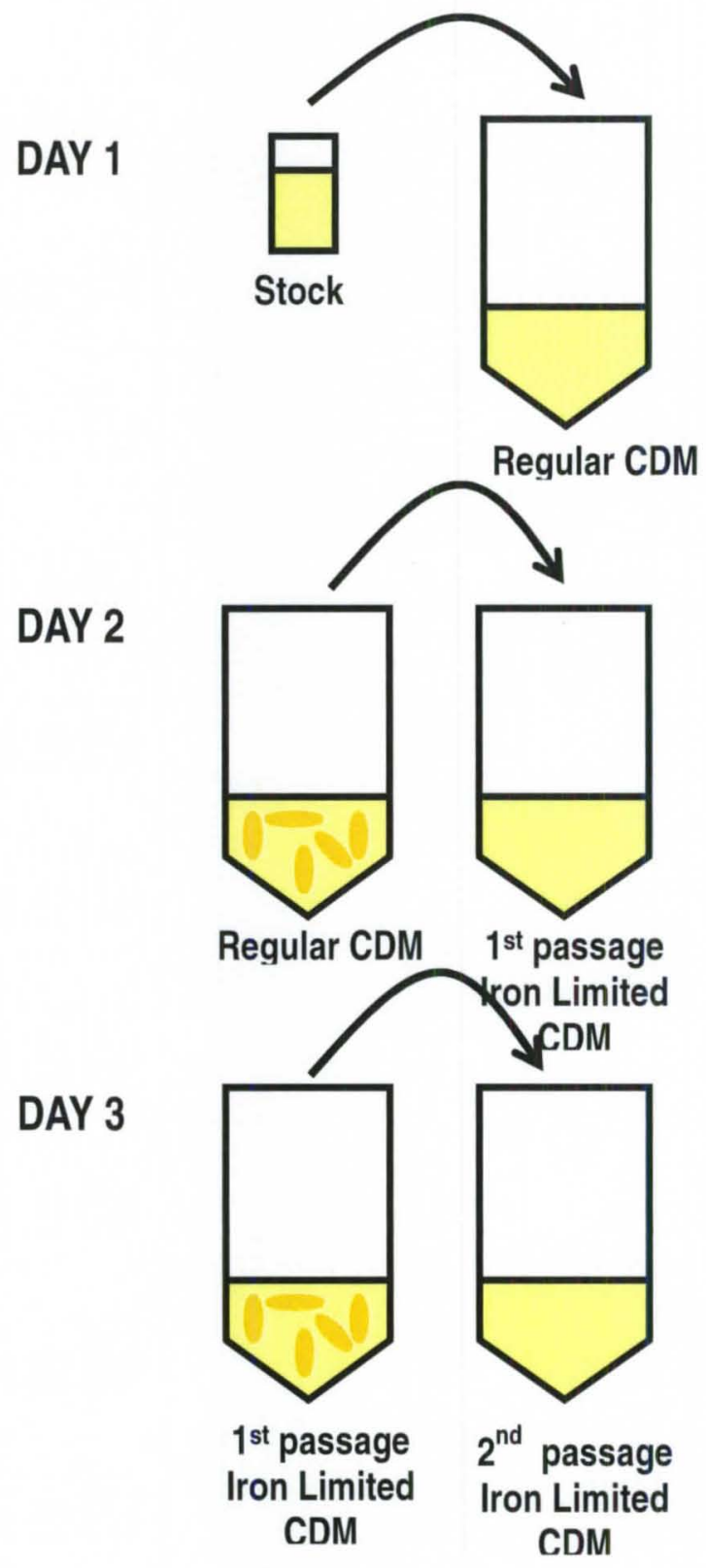

Figure 3: Achievement of an iron limited and iron chelated environment.

Diagram shows how $A$. actinomycetemcomitans was passaged in order to achieve an iron limited environment. The same mechanism was utilized in order to obtain an iron chelated environment except in an iron chelated environment an iron chelator, dypridyl (DIP), was added to the CDM No Iron at $100 \mathrm{uM}, 150 \mathrm{uM}$, and $200 \mathrm{uM}$ concentrations respectively. 
RNA Isolation. Overnight cultures of the appropriate A. actinomycetemcomitans incubated at $37^{\circ} \mathrm{C}$ until the mid-exponential growth phase (O.D. of .08 for $1^{\text {st }}$ passage CDM No Iron with $150 \mathrm{uM}$ DIP and .028 for $2^{\text {nd }}$ passage CDM No Iron with $150 \mathrm{uM}$ DIP) for RNA isolation. Total RNA was isolated from A. actinomycetemcomitans cells using the 5 Prime PerfectPure RNA Cell \& Tissue kit (5 Prime Inc., Gaithersburg, MD) according to the manufacturer's instructions. To ensure that the samples were free of contaminating genomic DNA, the RNA preparation was digested with RQ RNase-free DNase I (Promega Corporation, Madison, WI). The concentration and purity of each RNA sample were measured via spectrophotometry (ND-1000 Spectrophotometer, NanoDrop Technologies, Inc, Wilmington, DE) and was also assessed by gel electrophoresis. Samples were checked for contamination of genomic DNA by real-time PCR using A. actinomycetemcomitans 5s rRNA primers (Table 2) RNA samples were considered free of significant genomic DNA if no amplification product was detected by real-time PCR after at least 30 cycles of amplification. RNA that was not immediately utilized for a reverse-transcription reaction was aliquoted into $1.5 \mathrm{ml}$ Eppendorf tubes and stored at $-80^{\circ} \mathrm{C}$ until future use. 
cDNA synthesis and qPCR for iron acquisition gene expression. First-strand cDNA was prepared by using SuperScript III Reverse Transcriptase (Invitrogen, Carlsbad, CA) according to the manufacturer's instructions. Quantitative PCR (qPCR) was performed with the Smart Cycler system (Cepheid, Sunnyvale, CA) in a final reaction volume of $25 \mu \mathrm{l}$ that contained $100 \mathrm{ng}$ of cDNA, appropriate iron acquisition primers (5' Induction and 3' Induction; $\sim 71 \mu \mathrm{M}$ final concentration), and 1x FastStart SYBER Green Master (Roche, Indianapolis, IN). The amplification conditions for qPCRs were as follows: denaturation at $95^{\circ} \mathrm{C}$ for 15 seconds, annealing at $55^{\circ} \mathrm{C}$ for 30 seconds, and elongation at $72{ }^{\circ} \mathrm{C}$ for 30 seconds for 35 cycles. The threshold cycle for each qPCR was determined from a second derivative plot of total fluorescence as a function of cycle number by using the software package supplied with the Smart Cycler system. All genespecific threshold values were normalized against threshold values from primers specific for the $A$. actinomycetemcomitans $5 \mathrm{~S}$ rRNA gene ( $60 \mu \mathrm{M}$ final concentration). qPCR reactions were carried out in triplicate with consistent results. Each qPCR end-point amplification product was visualized by electrophoresis on $2 \%$ agarose gels. Primers utilized in this study included afuA 1642 (iron III ABC transporter), afuA 0696 (periplasmic iron-compund binding protein), hgpA 0696 (hemoglobin binding protein A), $f e c B 0795$ (iron III dicitrate-binding protein), and ftnA 2120 (nonheme ferritin) (54). 


\section{CHAPTER THREE: EXPRESSION OF IRON ACQUISTION GENES}

\section{Introduction:}

Dental plaque forms on surfaces of teeth and is composed of a dynamic micriobial community. As this microbial community matures, there is an increase in gram negative bacteria and decrease in gram positive bacteria. As gram negative bacteria proliferate in the oral biofilm, the host immune system reacts to the microbes, and eventually leads to periodontal disease. A. actinomycetemcomitans, is a gram negative coccibacillus, that is associated with the aggressive forms of periodontal disease. However in order for bacteria such as $A$. actinomycetemcomitans, to proliferate inside a human a host, iron is needed. Iron is an essential element needed for growth and normal metabolic functions in all organisms. Because the human host regulates iron, thus keeping a bacteriostatic environment, bacteria must overcome this iron sequesteration by encoding in its genome iron acquisition systems, in order to obtain iron from the host environment so that the bacteria may thrive and proliferate. Research to date has shown that $A$. actinomycetemcomitans has at least 15 iron aquistion genes encoded in its genome. The iron acquisition systems encoded in the genome of $A$. actinomycetemcomitans are tailored towards the specific survival strategies needed to survive in the oral biofilm. Due to all of the capability that $A$. actinomycetemcomitans has to obtain iron, there must be some dicression or priority in what type of iron A. actinomycetemcomitans prefers to utilize for 
growth. Due to the redundancy of ferric iron transporters in A. actinomycetemcomitans geneome and the major iron sources that $A$. actinomycetemcomitans will encounter to in the oral cavity lead us to our hypothesis that A. actinomycetemcomitans primarily utilizes ferric iron, obtained from iron chelators or host proteins, and hemic as iron sources in the oral cavity.

\section{Results:}

\section{A. actinomycetemcomitans is capable of growing in an iron-limited} environment. In order for us to test A. actinomycetemcomitans' ability to grow in an environment that lacked an iron source, A. actinomycetemcomitans was first grown in an iron rich media (CDM regular) overnight in an incubator at 37C. One milliliter of overnight planktonic cultures of A. actinomycetemcomitans strain 652 grown in CDM regular was inoculated into fresh CDM $19 \mathrm{~mL}$. Growth was analyzed for 12 hours by measuring the Optical Density at $600 \mathrm{~nm}$ every hour. The first passage with no iron culture was achieved by inoculating from an overnight culture of $A$. actinomycetemcomitans grown in CDM regular into fresh CDM with no added iron source (CDM No Iron). The second passage CDM No Iron culture was achieved by inoculating from an overnight culture of A. actinomycetemcomitans grown in the first passage of CDM No Iron. The third passage CDM No Iron culture was achieved by inoculating from an overnight culture of A. actinomycetemcomitans grown in the second passage of CDM No Iron. Results shown in Figure 4 are averages of O.D. \pm standard deviations. 


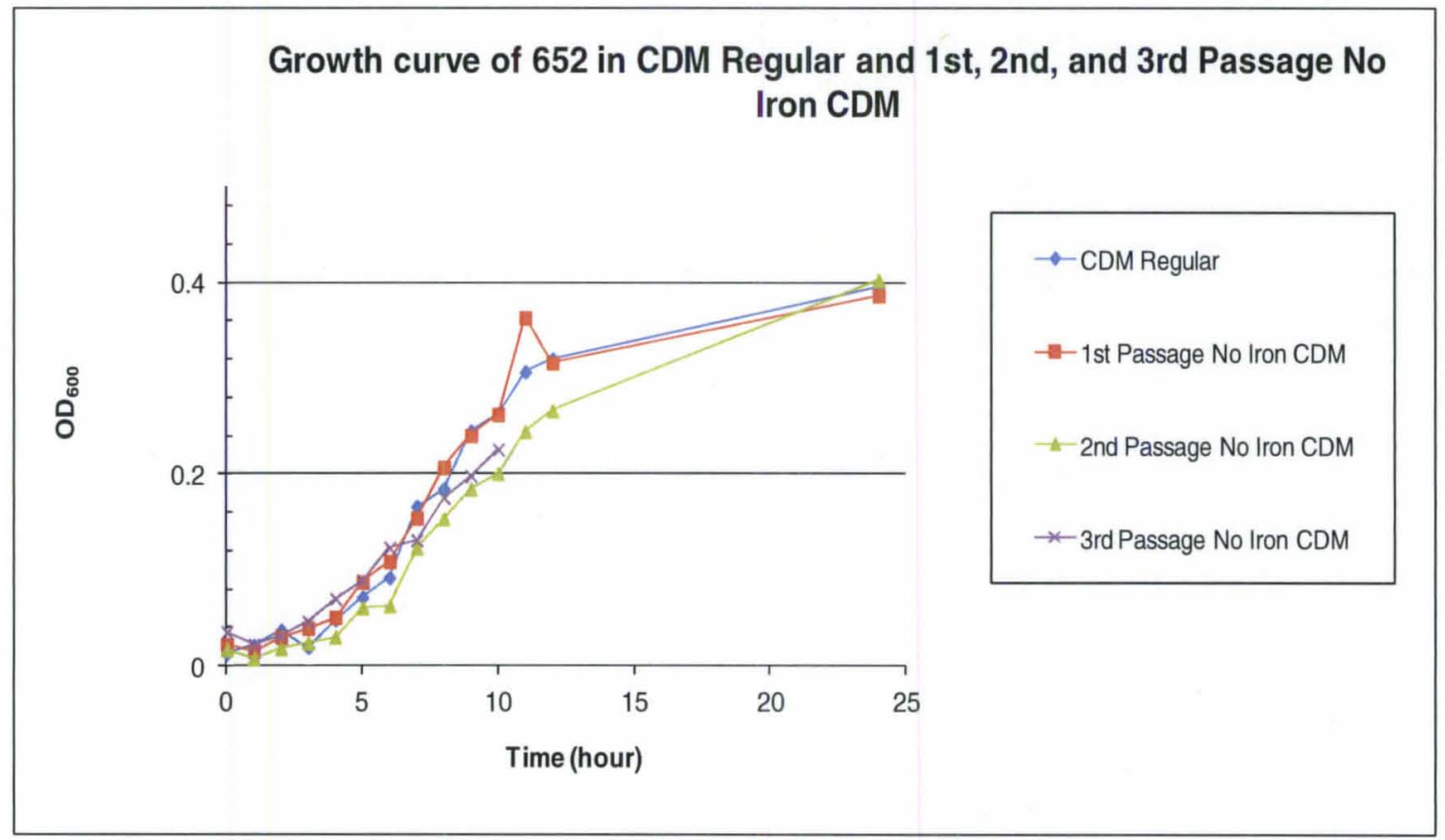

Figure 4. Growth of $A$. actinomycetemcomitans in an iron-limited environment. Growth of A. actinomycetemcomitans measured by spectrometery O.D. $600 \mathrm{~nm}$. Growth was measured in triplicates, results of growth were averages \pm standard deviations.

Results showed that A. actinomycetemcomitans was able to grow in an iron limited environment. Growth occurred similarily in all 3 passages of $A$. actinomycetemcomitans without an iron source. These results lead us to a couple of conclusions, either A. actinomycetemcomitans was capable of growing very well in an iron limited environment due to large internal iron storage system that lasted the bacteria well into the third passage or there were trace amounts of iron in media CDM No Iron, even though no exogenous iron source was added to the media. This lead us to to our second experiement of obtaining an iron-chelated environment. 


\section{An iron-chelated environment reduces the growth of $A$.}

actinomycetemcomitans. Passages in an iron chelated environment were achieved as described above in Figure 4. However, the growth of $A$. actinomycetemcomitans was analyzed in an iron-chelated enivornment at different concentrations of dypyridyl (DIP). Growth was analyzed for 12 hours by measuring the Optical Density at $600 \mathrm{~nm}$ every hour, as above. Figure 5a. DIP was added to the $1^{\text {st }}$ and $2^{\text {nd }}$ passages at $100 \mu \mathrm{M}$. Figure 5b. DIP was added to the $1^{\text {st }}$ and $2^{\text {nd }}$ passages at $150 \mu \mathrm{M}$. and Figure $5 \mathrm{c}$. DIP was added to the $1^{\text {st }}$ and $2^{\text {nd }}$ passages at $200 \mu \mathrm{M}$. Results are averages O.D. at $600 \mathrm{~nm} \pm$ standard deviations. 


\section{Overlay of 652 Growth in Regular CDM and 1st and 2nd Passages In No Iron CDM with 100 uM DIP}

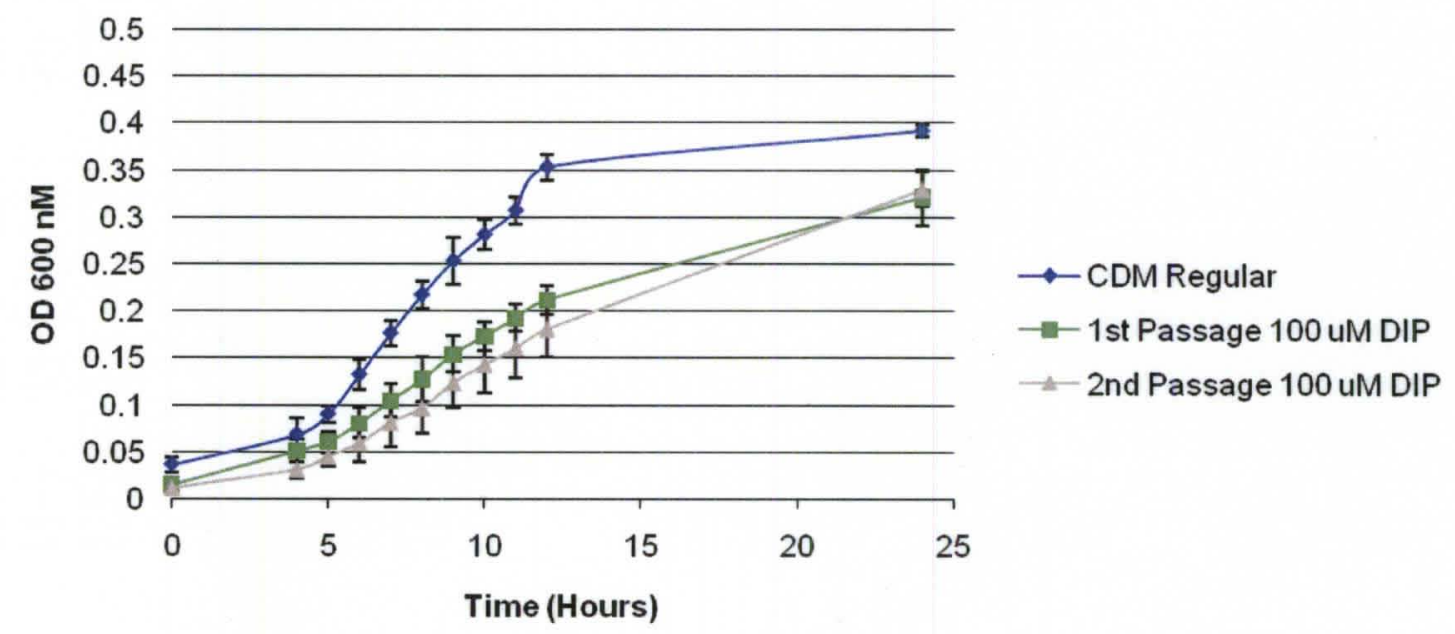

Figure 5a. Achievement of an Iron Chelated Environment with 100 uM DIP.

Growth of A. actinomycetemcomitans measured by spectrometery O.D. $600 \mathrm{~nm}$. Growth was measured in triplicates, results of growth were averages \pm standard deviations. 
Overlay of 652 Growth in Regular CDM and 1st and 2nd Passages in No Iron CDM with 150 uM DIP

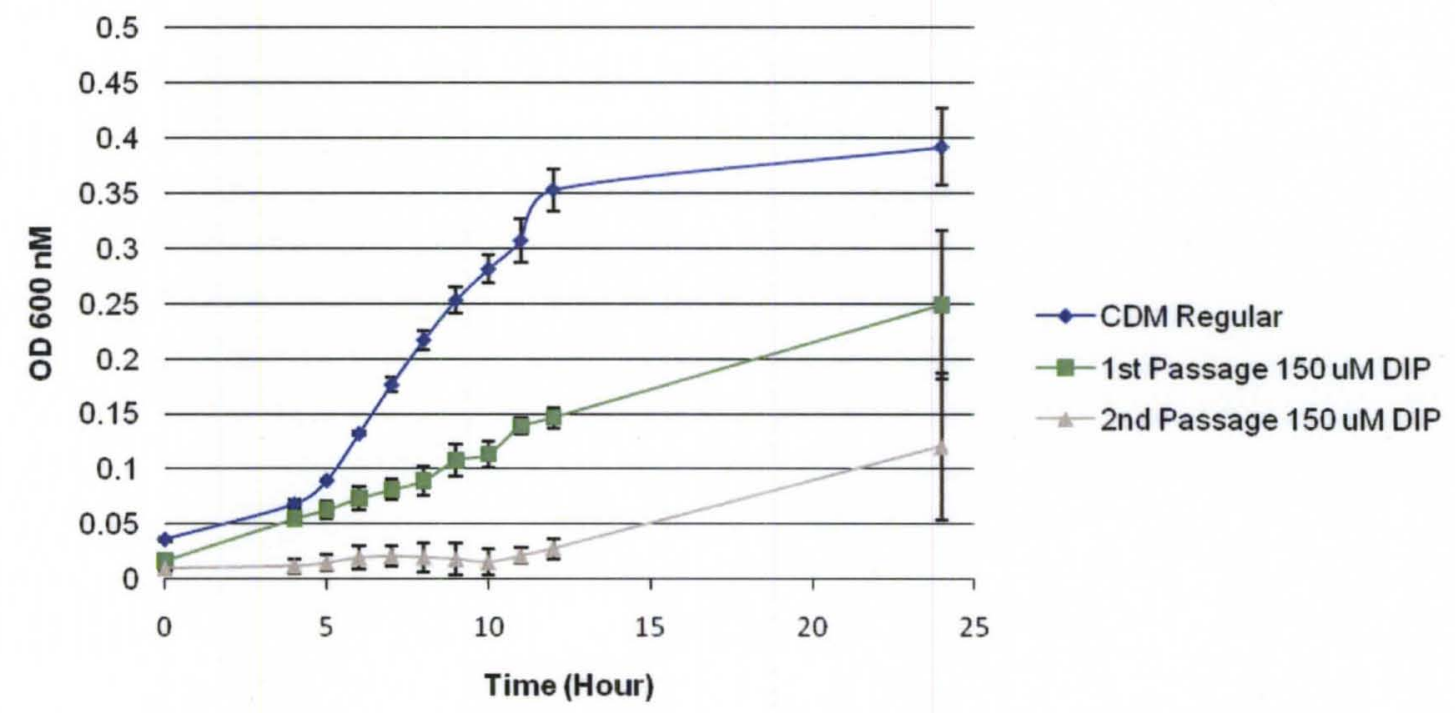

Figure 5b. Achievement of an Iron Chelated Environment with $150 \mathrm{uM} \mathrm{DIP.}$ Growth of A. actinomycetemcomitans measured by spectrometery O.D. $600 \mathrm{~nm}$. Growth was measured in triplicates, results of growth were averages \pm standard deviations. 


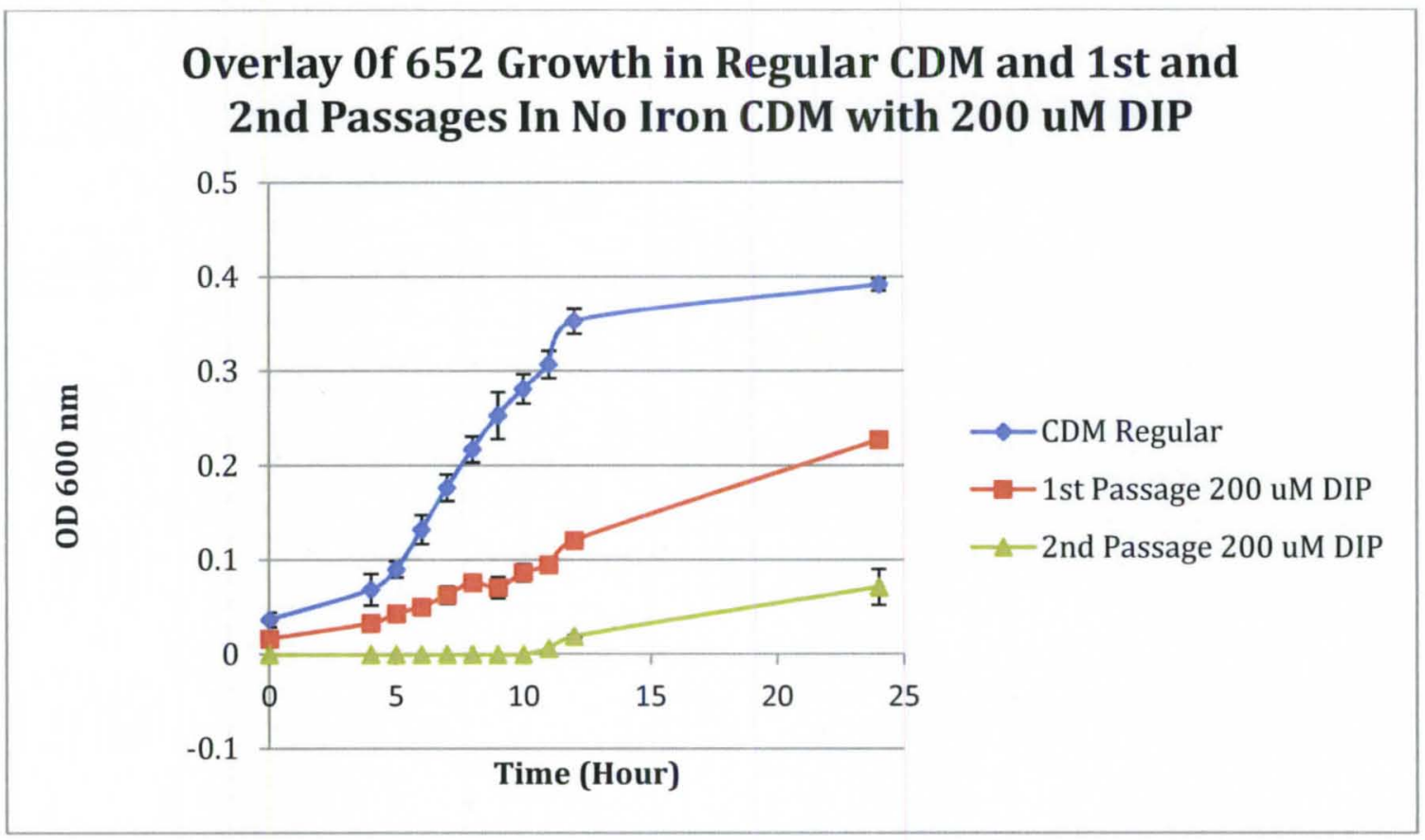

Figure 5c. Achievement of an Iron Chelated Environment with $200 \mathrm{uM}$ DIP.

Growth of A. actinomycetemcomitans measured by spectrometery O.D. $600 \mathrm{~nm}$. Growth was measured in triplicates, results of growth were averages \pm standard deviations.

Results from these growth analyses displayed that an iron-chelated environment reduces the growth of A. actinomycetemcomitans. It also proved that $A$. actinomycetemcomitans has an internal iron storage system that allows growth in an iron chelated environment well into the $1^{\text {st }}$ passage. However by the $2^{\text {nd }}$ passage of $A$. actinomycetemcomitans in an iron chelated environment the internal iron storage system had been depleted and A. actinomycetemcomitans growth was drastically reduced. It also proved that there were trace elements of iron in the No Iron CDM media that $A$. actinomycetemcomitans was able to utilize for growth. Now that an environment was created in which A. actinomycetemcomitans was depleted of all sources, we then decided 
to add different sources of iron in order to see what types of iron that $A$.

actinomycetemcomitans preferred to utilize for growth.

Growth of $\boldsymbol{A}$. actinomycetemcomitans utilizing different iron sources. To

determine A. actinomycetemcomitans' ability to utilize iron sources for growth, the $1^{\text {st }}$ passage CDM No Iron with $150 \mu \mathrm{M}$ DIP was inoculated into fresh CDM No Iron with $150 \mu \mathrm{M}$ DIP medium supplemented with $250 \mu \mathrm{M}$ of hemin, ferric chloride, ferric citrate, or ferrous sulfate. To prevent ferrous sulfate from oxidizing to ferric sulfate, the growth was analyzed under anaerobic conditions. The $1^{\text {st }}$ passage was achieved as in Figure 3. Growth was analyzed for 12 hours by measuring the Optical Density at $600 \mathrm{~nm}$ every hour. Results are averages of O.D. at $600 \mathrm{~nm} \pm$ standard deviations. 


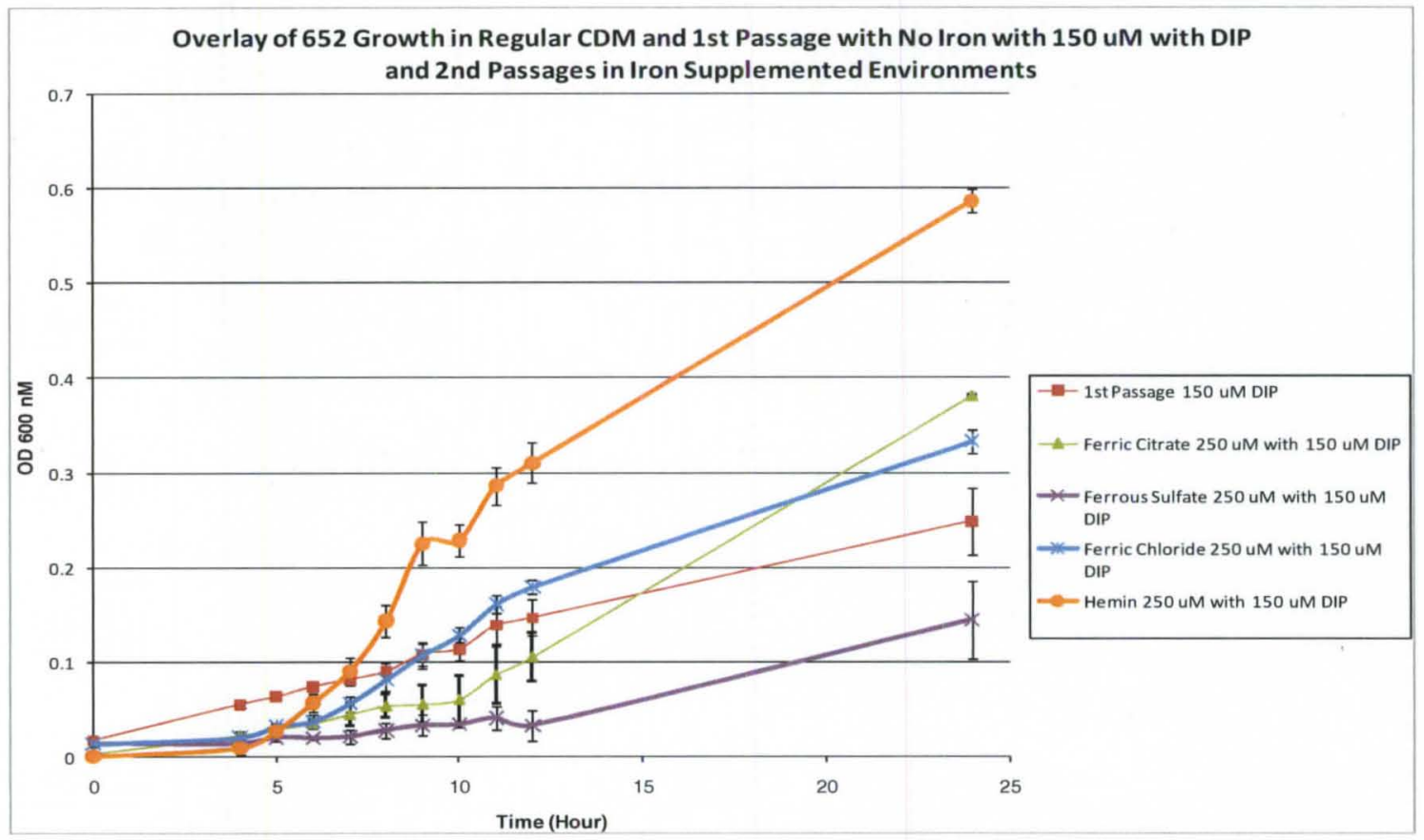

Figure 6. Growth of A. actinomycetemcomitans utilizing different iron sources

with $150 \mathrm{uM}$ DIP and $250 \mathrm{uM}$ of appropriate iron sources. Growth of $A$. actinomycetemcomitans measured by spectrometery O.D. $600 \mathrm{~nm}$. Growth was measured in triplicates, results of growth were averages \pm standard deviations.

Hemin, Ferric Chloride, and Ferric Citrate are iron sources that $A$. actinomycetemcomitns is capable of utilizing for growth. Growth of $A$. actinomycetemcomitans in ferrous sulfate was similar to the amount of growth that was witnessed in the $2^{\text {nd }}$ passage in an iron chelated environment leading us to the the conclusion that A. actinomycetemcomitans appears to not to be able to utilize ferrous sulfate as effectively for growth. Now that $A$. actinomycetemcomitans growth was analyzed under different iron conditions, we wanted to see what particular iron genes were up regulated or down regulated during these various iron conditons. 


\section{Expression of iron-uptake genes under an iron-chelated environment.}

Cultures utilized in this experiment were achieved as described in Figure 2. RNA was extracted mid exponential phase (O.D. of .08 for the first passage in CDM no iron and O.D. of .025 for the second passage in CDM no iron). RNA was isolated and CDNA was synthesized as described in the previous methods. Real-time PCR was performed using primers specific for iron genes. Iron genes utilized in this study were chosen based on the genes association with qorum sensing, due to the fact that previous research has shown that iron acquisition in A. actinomycetemcomitans is regulated by qorum sensing (72). Expression of genes are normalized to ${ }^{1 \text { st }}$ passage expression. Results are averages of Delta $T \pm$ standard deviations. Delta $T$ was calculated by subtracting the cycle threshold (Ct) determined for the each particular iron gene reaction from the $\mathrm{Ct}$ of the $5 \mathrm{~s}$ rRNA control.

Table 4a. afuA 1642 (iron (III) ABC transporter

\begin{tabular}{|c|c|c|c|}
\hline & delta T & delta (delta T) & Fold Change \\
\hline $\begin{array}{c}2^{\text {nd }} \text { Passage in } \\
\text { CDM No Iron with }\end{array}$ & $9.52 \pm 1.008$ & $0.0013 \pm 0.8 \mathrm{E}-3$ & $\mathbf{0 . 1 3 4} \pm \mathbf{3 . 3 5 0}$ \\
150 uM DiP & & & \\
\hline $\begin{array}{c}\mathbf{1}^{\text {st }} \text { Passage in CDM } \\
\text { No Iron with 150 } \\
\text { uM DIP }\end{array}$ & $6.63 \pm 0.001$ & $0.010 \pm 0.7 \mathrm{E}-3$ & 1 \\
\hline
\end{tabular}

delta $\mathrm{T}$ was calculated by subtracting the cycle threshold $(\mathrm{Ct})$ determined for the afuA 01642 reaction from the $\mathrm{Ct}$ of the 5s rRNA control. $\mathrm{P}$ value $=0.031$ 
Table 4b. afuA 0696 (periplasmic iron-compound-binding protein)

\begin{tabular}{|c|c|c|c|}
\hline & delta T & delta (delta T) & Fold Change \\
\hline $2^{\text {nd }}$ Passage in & $13.68 \pm 0.601$ & $7.62 \mathrm{E}-5 \pm 0.03 \mathrm{E}-3$ & $9.52 \pm .081$ \\
150 uM DIP & & & \\
\hline $\begin{array}{c}\text { No Iron with 150 } \\
\text { st Passage in CDM }\end{array}$ & $15.87 \pm 0.467$ & $8 \mathrm{E}-6 \pm 0.002 \mathrm{E}-3$ & 1 \\
\hline
\end{tabular}

delta $\mathrm{T}$ was calculated by subtracting the cycle threshold $(\mathrm{Ct})$ determined for the afuA

0696 reaction from the $\mathrm{Ct}$ of the 5s rRNA control. $\mathrm{P}$ value $=0.0150$

Table 4c. hgpA 0762 (hemoglobin binding protein A)

\begin{tabular}{|c|c|c|c|}
\hline & delta T & delta (delta T) & Fold Change \\
\hline $2^{\text {nd }}$ Passage in & $9.133 \pm 1.100$ & $0.002 \pm .001$ & $.319 \pm .241$ \\
150 uM DIP & & & \\
\hline $1^{\text {st }}$ Passage in CDM & $7.486 \pm 0.962$ & $0.006 \pm .004$ & 1 \\
No Iron with 150 & & & \\
uM DIP & & & \\
\hline
\end{tabular}

delta $\mathrm{T}$ was calculated by subtracting the cycle threshold $(\mathrm{Ct})$ determined for the $h g p A$

0762 reaction from the $\mathrm{Ct}$ of the 5s rRNA control. $\mathrm{P}$ value $=0.0978$ 
Table 4d. fecB 0795 (iron(III) dicitrate-binding protein

\begin{tabular}{|c|c|c|c|}
\hline & delta T & delta (delta T) & Fold Change \\
\hline $2^{\text {nd }}$ Passage in & $2.06 \pm .064$ & $0.240 \pm .011$ & $2.02 \pm .007$ \\
150 uM DIP & & & \\
\hline $1^{\text {st }}$ Passage in CDM & $3.076 \pm 0.050$ & $0.119 \pm .004$ & 1 \\
No Iron with 150 & & & \\
uM DIP & & & \\
\hline
\end{tabular}

delta $\mathrm{T}$ was calculated by subtracting the cycle threshold $(\mathrm{Ct})$ determined for the $f e c B$

0795 reaction from the $\mathrm{Ct}$ of the $5 \mathrm{~s}$ rRNA control. $\mathrm{P}$ value $=0.0003$

Table 4e. ftnA 2120 (nonheme ferritin)

\begin{tabular}{|c|c|c|c|}
\hline & delta T & delta (delta T) & Fold Change \\
\hline $2^{\text {nd }}$ Passage in & $8.009 \pm .003$ & $0.004 \pm 0.004$ E-3 & $.809 \pm 0.286$ \\
150 uM DIP & & & \\
\hline $1^{\text {st }}$ Passage in CDM & $7.704 \pm .424$ & $0.005 \pm .001$ & 1 \\
No Iron with 150 & & & \\
uM DIP & & & \\
\hline
\end{tabular}

delta $\mathrm{T}$ was calculated by subtracting the cycle threshold $(\mathrm{Ct})$ determined for the $f e c B$ 0795 reaction from the $\mathrm{Ct}$ of the $5 \mathrm{~s}$ rRNA control. $\mathrm{P}$ value $=0.0816$ 


\section{Discussion:}

Target genes utilized in this study were chosen due to the fact that previous research has shown that iron acquisition in A. actinomycetemcomitans are regulated by qorum sensing (58). The target genes in this study were associated with quorum sensing. Results showed that in an iron chelated environment, iron uptake genes of $A$. actinomycetemcomitans are differentially regulated. Using the $1^{\text {st }}$ passage as a starting point presented as a potential limitation. CDM regular, media containing an iron source, should have been baseline and as we started to starve the bacteria we could have witnessed differential regulation in gene expression. Real time PCR results were normalized to the ${ }^{1 \text { st }}$. AfuA 1642 , an iron III ABC transporter, was ultimately turned down during the second passage in CDM No Iron with 150 uM DIP. AfuA 0696 showed an up regulation of the gene during the $2^{\text {nd }}$ passage in CDM No Iron with $150 \mathrm{uM} \mathrm{DIP.}$ This was a very interesting result. AfuA 1642 showed down regulation during the $2^{\text {nd }}$ passage and $A f u A 0696$ showed an up regulation during the $2^{\text {nd }}$ passage. This suggest that there may be some distinction between these two ferric iron transporters. It may be possible that under very limiting iron conditions that $A$. actinomycetemcomitans is upregulating ferric iron transport that may be specific for iron coming from a particular source and the other $\mathrm{ABC}$ transporter may be down regulated because it is intended to transport iron obtained from a different source.. While cells are starving, there seems to be an upregulation of $a f u A 0696$ and $f e c B$ 0795, an iron (III) $\mathrm{ABC}$ transporter, and a iron (III) dicitrate binding protein (scavenging system) respectively. The gene regulation of ftnA 2120 essentially stayed the same in the first and the second passage. This makes sense that $f \operatorname{tn} A 2120$ is not being regulated at all considering it is essentially an iron 
storage molecule. There was down regulation of the hemoglobin binding protein, $h g p A$ 0762 and afuA 0696. What is interesting is that there are three different afuA annotated gene clusters in A. actinomycetemcomitans, and all three have different sequences. This may suggest that these genes may differentially expressed, may have different functions, and may be expressed under different conditions.

Due to the fact that $A$. actinomycetemcomitans possess a wide variety of potential mechanisms to obtain iron sources, of the iron acquisition genes encoded in $A$. actinomycetemcomitans genome, A. actinomycetemcomitans differentially expresses genes according to what environment it is in and what different iron sources it is exposed to. 


\section{CHAPTER FOUR: SUMMARY AND FUTURE DIRECTIONS}

Iron is the most abundant metal in nature, and as such plays a major role in many life processes of all organisms. In the human host, iron is highly regulated, creating a bacteriostatic environment. However in order for organisms to survive they must be able to overcome this iron limitation by encoding in their genome iron aquisition systems. Research to date has revealed that $A$. actinomycetemcomitans has encoded in its genome at least 15 iron aquisition systems to overcome this bacteriostatic environment (67). The iron acquisition systems enoded in A. actinomycetemcomitans are tailored towards the specific survival strategies needed to survive in the oral biofilm. Thus $A$. actinomycetemcomitans is expected to be able to utilize inorganic and organic as well as ferric and ferrous iron sources both in planktonic culture and biofilms. These particular findings were expected due to the redundancy of ferric iron transporters in $A$. actinomycetemcomitans genome, and the particular iron sources that $A$. actinomycetemcomitans encounters in the oral cavity. In this study, we investigated the planktonic growth of $A$. actinomycetemcomtians in an iron-limited and iron-chelated environment as well as analyze the ability of $A$. actinomycetemcomitans to grow in an iron-chelated environment supplemented with different iron sources and investigate what particular iron aquistion genes are being upregulated in an iron chelated environment. 
We discovered that A. actinomycetemcomtians is capable of growing in an iron limited environment, that though there wasn't a external iron source added to the media that $A$. actinomycetemcomitans was able to scavage trace amounts of iron from other chemicals in the CDM, and efficiently use it for growth. However $A$. actinomycetemcomitans was not capable of growing in an iron chelated environment. By the second passage in an iron chelated environment A. actinomycetemcomitans growth was drastically reduced. This lead us to the conclusion that $A$. actinomycetemcomitans has an excellent internal iron storage system that the bacteria is capable of using for growth during the first passage of growth but is not large enough to use for growth during the second passage. The reduction of growth of the bacteria in an iron-chelated environment occurred in a dose dependent manner.

Growth of A. actinomycetemcomitans utilizing $250 \mathrm{uM}$ of ferric citrate, ferric chloride, and hemin respectively with 150 uM DIP restored growth to the levels above the $1^{\text {st }}$ passage in an iron chelated environment. Growth of $A$. actinomycetemcomitans was higher in an hemin iron environment, suggesting that A. actinomycetemcomitans prefers hemin as an iron source. However A. actinomycetemcomitans growth in a ferrous sulfate iron source was very low. It was very similar to the amount of growth that was witnessed in the $2^{\text {nd }}$ passage in an iron-chelated environment leading us to the conclusion that $A$. actinomycetemcomitans appears to not to be able to utilize ferrous sulfate as effectively for growth. This was not suprising considering the analysis of $A$. actinomycetemcomitans genome did not reveal in iron acquisition genes for ferrous iron sources. However we thought that because $A$ actinomycetemcomitans is an anaerobic 
bacteria, that in an anerobic environment that A. actinomycetemcomitans may be able to utilize the non oxidized ferrous iron source.

Results from Realtime PCR showed that in an iron chelated environment, iron uptake genes of $A$. actinomycetemcomitans are differentially regulated. Using the $1^{\text {st }}$ passage as a starting point presented as a potential limitation. CDM regular, media containing an iron source, should have been baseline and as we started to starve the bacteria we could have witnessed differential regulation in gene expression. Real time PCR results were normalized to the $2^{\text {nd }}$ passage and what was seen was afuA 1642 showed a 7 fold increase than in the $1^{\text {st }}$ passage compared to the $2^{\text {nd }}$ passage. AfuA 0696 showed a 10 fold higher increase than in the $2^{\text {nd }}$ passage that in the $1^{\text {st }}$ passage. While cells are starving, there seems to be an upregulation of afuA 0696 and fecB 0795 , and iron (III) $\mathrm{ABC}$ transporter, and a iron (III) dicitrate binding protein (scavenging system) respectively. The gene regulation of ftnA2120 essentially stayed the same in the first and the second passage. This makes sense that ftnA 2120 is not being regulated at all considering it is essentially and iron storage molecule. There was a down regulation of the hemoglobin binding protein and afuABC 0696. What is interesting is that there are three different afuA annotated gene clusters in A. actinomycetemcomitans, and all three have different sequences. This may suggests that these genes may differentially expressed may have different functions, and may be expressed under different conditions.

Though many questions have had some light shed on them during my research, more research still needs to be done. Ultimately the original idea of my research was to first look at the expression of a couple of these iron acquisition systems under the initial iron conditions used, in other words the $1^{\text {st }}$ and $2^{\text {nd }}$ passages in CDM No Iron with 150 
uM DIP. After the expression of the iron acquisition genes were established under the iron chelated conditions, our goal then was to add back specific iron sources and see what happened to gene expression with the different iron operons under these different iron conditions. The first part of our goal we accomplished, however the second part is a project that a future student will carry on. I also only focused on a limited numbers of operons, in the future more iron acquisition genes should be included. Also to make my research show more validity, mutant strains of $A$. actinomycetemcomitans should be formulated, knocking out specific iron operons and testing the growth and gene regulation under the different iron conditions. Because past and current research all describe A. actinomycetemcomitans as growing in a biofilm, more studies on iron aqusition genes with $A$. actinomycetemcomitans grown in a biofilm formation are needed if there are any hopes in formulating a chelator that is strong enough to chelate the preferred iron source of A. actinomycetemcomitans, that the human host is also able to tolerate. 


\section{REFERENCES}

1. Aas, J. A., B. J. Paster, L. N. Stokes, I. Olsen, and F. E. Dewhirst. 2005. Defining the normal bacterial flora of the oral cavity. Journal of Clinical Microbiology 43:5721-5732.

2. Alugupalli, K., R., Kalfas, S., Edwardsson, S., Naidu, A., S., 1995. Lactoferrin interaction with Actinobacillus actinomycetemcomitans. Oral Microbiol Immunol 10: $35-41$.

3. Armitage, G. C. 1995. Clinical evaluation of periodontal diseases. Periodontology 2000 7:39-53.

4. Baelum, V., and R. Lopez. 2003. Defining and classifying periodontitis: need for a paradigm shift? European Journal of Oral Sciences 111:2-6.

5. Baker, P. J. 2000. The role of immune responses in bone loss during periodontal disease. Microbes and Infection 2:1181-1192.

6. Bergstrom, J., S. Eliasson, and J. Dock. 2000. Exposure to tobacco smoking and periodontal health. Journal of Clinical Periodontology 27:61-68.

7. Bostrom, L., J. Bergstrom, G. Dahlen, and L. E. Linder. 2001. Smoking and subgingival microflora in periodontal disease. Joural of Clinical Periodontology 28:212-219.

8. Brogan, J. M., E. T. Lally, K. Poulsen, M. Kilian, and D. R. Demuth. 1994. Regulation of Actinobacillus actinomycetemcomitans leukotoxin expression: analysis of the promoter regions of leukotoxic and minimally leukotoxic strains. Infection and Immunity 62:501-508.

9. Brown, L. J., B. A. Johns, and T. P. Wall. 2002. The economics of periodontal diseases. Periodontology 2000 29:223-234.

10. Darby, I. B., P. J. Hodge, M. P. Riggio, and D. F. Kinane. 2005. Clinical and microbiological effect of scaling and root planing in smoker and non-smoker chronic and aggressive periodontitis patients. Journal of Clinical Periodontology 32:200-206.

11. Darveau, R. P., A. Tanner, and R. C. Page. 1997. The microbial challenge in periodontitis. Periodontology 2000 14:12-32.

12.. Davies, D. G., M. R. Parsek, J. P. Pearson, B. H. Iglewski, J. W. Costerton, and E. P. Greenberg. 1998. The involvement of cell-to-cell signals in the development of a bacterial biofilm. Science 280:295-298.

13. Deshpande, R. G., M. B. Khan, and C. A. Genco. 1998. Invasion of aortic and heart endothelial cells by Porphyromonas gingivalis. Infection and Immunity 66:5337-5343.

14. Diaz, P. I., N. I. Chalmers, A. H. Rickard, C. Kong, C. L. Milburn, R. J. 
infection composed of Porphyromonas gingivalis and Fusobacterium nucleatum. Microbial Pathogensis 23:23-32.

15. Eggert, F. M., M. H. McLeod, and G. Flowerdew. 2001. Effects of smoking and treatment status on periodontal bacteria: evidence that smoking influences control of periodontal bacteria at the mucosal surface of the gingival crevice. Journal of Periodontology 72:1210-1220.

16. Fine, D. H., D. Furgang, H. C. Schreiner, P. Goncharoff, J. Charlesworth, G. Ghazwan, P. Fitzgerald-Bocarsly, and D. H. Figurski. 1999. Phenotypic variation in Actinobacillus actinomycetemcomitans during laboratory growth: implications for virulence. Microbiology 145 ( Pt 6): 1335-1347.

17. Fives-Taylor, P. M., D. H. Meyer, K. P. Mintz, and C. Brissette. 1999. Virulence factors of Actinobacillus actinomycetemcomitans. Periodontology 2000 20:136-167.

18. Gibson, F. C., 3rd, T. Ukai, and C. A. Genco. 2008. Engagement of specific innate immune signaling pathways during Porphyromonas gingivalis induced chronic inflammation and atherosclerosis. Frontiers in Bioscience 13:2041-2059.

19. Gomes, S. C., F. B. Piccinin, R. V. Oppermann, C. Susin, C. I. Nonnenmacher, R. Mutters, and R. A. Marcantonio. 2006. Periodontal status in smokers and never-smokers: clinical findings and real-time polymerase chain reaction quantification of putative periodontal pathogens. Journal of Periodontology 77:1483-1490.

20. Graber, K., Smoot, L., Actis, L. 1998. Expression of iron binding proteins and hemin binding activity in the dental pathogen Actinobacillus actinomycetemcomitans. FEMS Microbiology Letters 163: 135-142.

21. Grenier, D,. Leduc, A., and Mayrand, D. 1997. Interaction between Actinobacillus actinomycetemcomitans lipopolysaccharides and human hemoglobin. FEMS Microbiology Letters 151:77-81.

22. Grenier, D., Huot, M., Mayrand, D. 2000. Iron-Chelating Activity of Tetracyclines and Its Impacts on the Susceptibility of Actinobacillus actinomycetemcomitans to These Antibiotics. Antimicrobial Agents and Chemotherapy 44: 763-766.

23. Grossi, S. G., and R. J. Genco. 1998. Periodontal disease and diabetes mellitus: a two-way relationship. Annuals of Periodontology 3:51-61.

24. Grossi, S. G., R. J. Genco, E. E. Machtei, A. W. Ho, G. Koch, R. Dunford, J. J. Zambon, and E. Hausmann. 1995. Assessment of risk for periodontal disease. II. Risk indicators for alveolar bone loss. Journal of Periodontology 66:23-29.

25. Grossi, S. G., J. J. Zambon, A. W. Ho, G. Koch, R. G. Dunford, E. E. Machtei, O. M. Norderyd, and R. J. Genco. 1994. Assessment of risk for periodontal disease. I. Risk indicators for attachment loss. Journal of Periodontology 65:260-267.

26. Haffajee, A. D., and S. S. Socransky. 2001. Relationship of cigarette smoking to the subgingival microbiota. Journal of Clinical Periodontology 28:377-388.

27. Haraszthy, V. I., Lally, E. T., Haraszthy, G. G., Zambon, J. J. 2002. Molecular Cloning of the fur Gene from Actinobacillus actinomycetemcomitans. Infection and immunity 70: 3170-3179. 
28. Herzberg, M. C., and M. W. Meyer. 1996. Effects of oral flora on platelets: possible consequences in cardiovascular disease. Journal of Periodontology 67:1138-1142.

29. Herzberg, M. C., and M. W. Weyer. 1998. Dental plaque, platelets, and cardiovascular diseases. Annuals Periodontology 3:151-160.

30. Holm, P. 1950. Studies on the etiology of human actinomycosis. I. The "other microbes" and their importance. Acta Pathologica Microbiologica Scandinavica 27:736-751.

31. Hritz, M., E. Fisher, and D. R. Demuth. 1996. Differential regulation of the leukotoxin operon in highly leukotoxic and minimally leukotoxic strains of Actinobacillus actinomycetemcomitans. Infection and Immunity 64:2724-2729.

32. Hugoson, A., H. Thorstensson, H. Falk, and J. Kuylenstierna. 1989. Periodontal conditions in insulin-dependent diabetics. Journal of Clinical Periodontology 16:215-223.

33. Hujoel, P. P., M. A. del Aguila, T. A. DeRouen, and J. Bergstrom. 2003. A hidden periodontitis epidemic during the 20th century? Community Dentistry and Oral Epidemiology 31:1-6.

34. Kachlany, S. C., P. J. Planet, R. DeSalle, D. H. Fine, and D. H. Figurski. 2001. Genes for tight adherence of Actinobacillus actinomycetemcomitans: from plaque to plague to pond scum. Trends in Microbiology 9:429-437.

35. Kilian, M., and C. R. Schiott. 1975. Haemophili and related bacteria in the human oral cavity. Archives of Oral Bioliogy 20:791-796.

36. Kinane, D. F. 1998. Periodontal diseases' contributions to cardiovascular disease: an overview of potential mechanisms. Annuals of Periodontology 3:142-150.

37. Kinane, D. F., D. R. Demuth, S. U. Gorr, G. N. Hajishengallis, and M. H. Martin. 2007. Human variability in innate immunity. Periodontology 2000 45:14-34.

38. Klinger, R. 1912. Untersuchungen iiber menschliche Aktinomykose. Zentralblat Bacteriol. Parasitenkd. Infektionskr. Hyg. Abt 62:191-200.

39. Loesche, W. J., and D. E. Lopatin. 1998. Interactions between periodontal disease, medical diseases and immunity in the older individual. Periodontology 2000 16:80-105.

40. Lovegrove, J. M. 2004. Dental plaque revisited: bacteria associated with periodontal disease. Journal of the New Zealand Society of Periodontology:7-21.

41. Martin, T. J., and N. A. Sims. 2005. Osteoclast-derived activity in the coupling of bone formation to resorption. Trends in Molecular Medicine 11:76-81.

42. McGuire, M. K., and M. E. Nunn. 1996. Prognosis versus actual outcome. III. The effectiveness of clinical parameters in accurately predicting tooth survival. Joural of Periodontology 67:666-674.

43. Meyer, D. H., J. E. Lippmann, and P. M. Fives-Taylor. 1996. Invasion of epithelial cells by Actinobacillus actinomycetemcomitans: a dynamic, multistep process. Infection and Immunity 64:2988-2997.

44. Morris, J. F., and D. L. Sewell. 1994. Necrotizing pneumonia caused by mixed infection with Actinobacillus actinomycetemcomitans and Actinomyces israelii: case report and review. Clinical Infectious Diseases 18:450-452. 
45. Nair, S. P., S. Meghji, M. Wilson, K. Reddi, P. White, and B. Henderson. 1996. Bacterially induced bone destruction: mechanisms and misconceptions. Infection and Immunity 64:2371-2380.

46. Offenbacher, S., J. D. Beck, S. Lieff, and G. Slade. 1998. Role of periodontitis in systemic health: spontaneous preterm birth. Journal of Dental Education 62:852-858.

47. Offenbacher, S., V. Katz, G. Fertik, J. Collins, D. Boyd, G. Maynor, R. McKaig, and J. Beck. 1996. Periodontal infection as a possible risk factor for preterm low birth weight. Journal of Periodontology 67:1103-1113.

48. Otto B., R., Verweij-van Vught, A., M., MacLaren, D., M. 1992. Molecular characterization of a heme-binding protein of Bacteroides fragilis BE1. Infect Immun.; 64(10): 4345-4350.

49. Palmer, R. M., R. F. Wilson, A. S. Hasan, and D. A. Scott. 2005. Mechanisms of action of environmental factors--tobacco smoking. Journal of Clinical Periodontology 32 Suppl 6:180-195.

50. Papapanou, P. N. 1996. Periodontal diseases: epidemiology. Annual Periodontology 1:1-36.

51. Phan, T. C., J. Xu, and M. H. Zheng. 2004. Interaction between osteoblast and osteoclast: impact in bone disease. Histology and Histopathology 19:1325-1344.

52. Pihlstrom, B. L., B. S. Michalowicz, and N. W. Johnson. 2005. Periodontal diseases. Lancet 366:1809-1820.

53. Rosan, B., J. Slots, R. J. Lamont, M. A. Listgarten, and G. M. Nelson. 1988. Actinobacillus actinomycetemcomitans fimbriae. Oral microbiology and Immunology 3:58-63.

54. Rhodes, E. R., Tomarus, A. P., McGillivary, G., Connerly, P. L., Actis, L,A. 2005. Genetic and Functional Analyses of Actinobacillus actinomycetemcomitans AfeABCD Siderophore-Independent Iron Acquisition System. Infection and Immunity 73: 3758-3763.

55. Rota, M. T., P. Poggi, L. Baratta, E. Gaeta, R. Boratto, and A. Tazzi. 1999. Tobacco smoke in the development and therapy of periodontal disease: progress and questions. Bulletin du Groupement international pour la recherche scientifique en stomatologie \& odontologie 41:116-122.

56. Scannapieco, F. A., and J. M. Mylotte. 1996. Relationships between periodontal disease and bacterial pneumonia. Journal of Periodontology 67:1114-1122.

57. Schenkein, H. A., S. E. Barbour, C. R. Berry, B. Kipps, and J. G. Tew. 2000. Invasion of human vascular endothelial cells by Actinobacillus actinomycetemcomitans via the receptor for platelet-activating factor. Infection and Immunity 68:5416-5419.

58. Shao, H., R. J. Lamont, and D. R. Demuth. 2007. Autoinducer 2 is required for biofilm growth of Aggregatibacter (Actinobacillus) actinomycetemcomitans. Infection and immunity 75 (9):421 1-4218.

59. Slots, J., H. S. Reynolds, and R. J. Genco. 1980. Actinobacillus actinomycetemcomitans in human periodontal disease: a cross-sectional microbiological investigation. Infection and Immunity 29:1013-1020. 
60. Socransky, S. S., A. D. Haffajee, M. A. Cugini, C. Smith, and R. L. Kent, Jr. 1998. Microbial complexes in subgingival plaque. Journal of Clinical Periodontology 25:134-144.

61. Taichman, N. S., D. L. Simpson, S. Sakurada, M. Cranfield, J. DiRienzo, and J. Slots. 1987. Comparative studies on the biology of Actinobacillus actinomycetemcomitans leukotoxin in primates. Oral Microbiology and Immunology 2:97-104.

62. Umeda, M., C. Chen, I. Bakker, A. Contreras, J. L. Morrison, and J. Slots. 1998. Risk indicators for harboring periodontal pathogens. Jouranl of Periodontology 69:1111-1118.

63. Vogel, H. J., Clarke, T., Tari, L. 2001. Structural Biology of Bacterial Iron Uptake Systems.. Current Topics in Medicinal Chemistry 1: 7-30.

64. Willemsen, P. T., Vulto, I., Boxem, M., De Graaff, J. 1997. Characterization of a Periplasmic Protein Involved in Iron Utilization of Actinobacillus actinomycetemcomitans. Journal of Bacteriology 179:4949-4952.

65. Winston J., L., Chen, C., K., Neiders, M., E., Dyer, D., W. 1993. Membrane protein expression by Actinobacillus actinomycetemcomitans in response to iron availability. J Dent Res 72: 1366-1373.

66. Zambon, J. J. 1985. Actinobacillus actinomycetemcomitans in human $p$ eriodontal disease. Journal of Clinical Periodontology 12:1-20.

67. Zambon, J. J., S. G. Grossi, E. E. Machtei, A. W. Ho, R. Dunford, and R. J. Genco. 1996. Cigarette smoking increases the risk for subgingival infection with periodontal pathogens. Jouranl of Periodontology 67:1050-1054.

68. Carton, M., L., Maddocks, S., Gillingham, P., Craven C. J., Andrews, S. 2006. Feo- Transport of ferrous iron into bacteria. Biometals 19: 143-157.

69. Mey, A., R., Wyckoff, E., E., Kanukurthy, V., Fisher, C., R., Payne, S., M. Iron and Fur regulation in Vibrio cholerae and the role of fur in virulence. 2005. Infect and Immun 73 (12): 8167-8178.

70. Wyckoff, E., E., Mey. A., R., Leimback, A., Fisher, C., F., Payne, S., M. 2006. Characterization of ferric and ferrous iron transport systems in Vibrio cholerae. $\mathrm{J}$ Bacteriol 188(18): 6515-6123. 


\section{CURRICULUM VITAE Porscha LaRai Jefferson, D.M.D.}

Birthday:

Citizenship:

Address:

Contact Information:

Higher Education

2000-2004

2004-2008

2008-2012

2010-current

2012-current
July 16,1986

U.S.A.

Work: University of Louisville

School of Dentistry Pediatric Department

501 South Preston St.

Louisville, Kentucky 40292

Home: 464 E. Brandeis Ave. Louisville Ky 40217

Cell: (502) 994-0389

Pljeff01@ cardmail.louisville.edu
Holmes High School Covington, Kentucky

-Work Ethic Diploma

-Holmes High School Diploma

-International Baccalaureate Diploma

University of Louisville

Louisville, Kentucky

B.A. (2004-2008)

University of Louisville School of Dentistry

Louisville, Kentucky

D.M.D.

University of Louisville School of Dentistry

Louisville, Kentucky

M.S.

University of Louisville School of Dentistry

Pediatric Department

Louisville, Kentucky

Pediatric Speciality Certificate 


\section{Academic Appointments:}

2011-2012

Biochemistry Academic Tutor

University of Louisville School of Dentistry

2011-2012

Aesthetics Academic Tutor

University of Louisville School of Dentistry

$2011-2012$

Oral Diagnosis and Oral Pharmacology Academic Tutor

University of Louisville School of Dentistry

2009-2012

Research Student

University of Louisville School of Dentistry

2009-2012

Head and Neck Anatomy Academic Tutor

University of Louisville School of Dentistry

$2009-2010$

Microbiology Academic Tutor

University of Louisville School of Dentistry

$2007-2008$

Upward Bound Academic Tutor

University of Louisville

Louisville, KY

\section{Honors and Academic Achievements}

2012

2012

2012

2012

2012

2012

2011

2011-2012
Oral Health and Systemic Research Award

American Academy of Pediatric Dentistry Award

Pierre Fauchard Award

Karen Andrus Award

Kentucky Off-site Clinical Community Service Scholar

Hispanic Dental Association U of L Chapter Award

The Hinman Research Symposium- Louisville Representative

Clinical Outreach Scholarship 
SNDA National Convention Delegate (Baltimore, Maryland)

SNDA Leadership Conference Delegate

2011

$3^{\text {rd }}$ Place in Research Louisville

2010-2012

2010

Student Representative on ULSD Admissions Committee

Student Representative for Outreach Scholar Committee

2010

2010

2010

2009

2010

2008-2010

2008-2012

2007

2006-2008

2006-2008

2004-2008

2004

2004

2004

2004

2004

Research Louisville Participant

$2^{\text {nd }}$ Place in Research Louisville

$2^{\text {nd }}$ Place in Research at SNDA National Research Competition

$4^{\text {th }}$ Place in Research at Student Convention

SNDA National Convention Delegate (Hawaii)

University of Louisville School of Dentistry Dean's List

General Dentistry Scholarship (Full Tuition)

MCAT/DAT Summer Program Participant

Alpha Epsilon Delta Health Honor Society

University of Louisville Dean's List

Woodford Porter Senior Scholarship (Full Tuition \& Room and Board)

Salutatorian

Louisville Book Award

Advanced Placement Social Studies Award

Key to the City of Covington for Academic Achievement

Northern Kentucky Coaches Association Cheerleading

Scholarship 
2003

2003

2002-2003

2002-2003

\section{Academic Positions}

2011

2010-2011

2010-2011

2010-2011

2009-2010

2008-2012

$2008-2010$

2008-2012

2004-2008

2004-2008

2003-2004

2003-2004

Work Experiences

2012-current

2012-current
Advanced Placement Math Award

Northern Kentucky University Spanish Award

Governor School for the Arts Participant

Governor Scholar Program Recipient
Student National Dental Association- President

American Association of Women Dentist- Secretary

Dental Class Secretary

Student National Dental Association- Social Chair

American Student Dental Association- General Member

American Dental Education Association- General Member

Psi Omega Dental Fraternity

Kappa Delta Sorority General Member

Alpha Epsilon Delta Pre Health Honor Society

Holmes High School Class President

National Honor Society President

Pediatric Dental Resident

University of Louisville School of Dentistry

Louisville Ky, 40208

Dentist

University of Louisville School of Dentistry Emergency Clinic Louisville Ky, 40208 
Dental Student

Park Duvalle Community Health Clinic

Louisville Ky, 40217

2008

Library Student Assistant

Kornhaeuser Library

Louisville Ky, 40208

2007-2008

Upward Bound Academic Tutor

University of Louisville

Louisville Ky, 40208

2005

Brand Representative

Abercrombie \& Fitch

Louisville Ky, 40208

2005

Sales Associate

Charolette Russe

Louisville Ky, 40208

2004-2006

Lifeguard

City of Covington Recreation Parks

Covington $\mathrm{Ky}, 41014$

2003-2006

Veterinarian Assistant

Ft. Wright Pet Care

Ft. Wright, Ky 40214

\section{Community Service}

2009-2011

Rural America Missions (Pikeville) Volunteer

$2008-2012$

Whitney Young Foundation Volunteer

2008-2012

Black Achievers Volunteer

$2008-2012$

Lincoln Foundation Volunteer

2008-2012

University of Louisville School of Dentistry Impressions

Program

$2008-2012$

Wayside Christian Services Soup Kitchen Volunteer

2008-2012

Angel Tree Volunteer 
$2008-2012$

2008-2011

2009-2011

2009-2012

2010

2011

2011
SNDA Canned Food Drive Volunteer

Presbyterian Fall Festival Volunteer

Beat the Pumpkin Volunteer

Spanish Health Fair Volunteer

Presbyterian Health Fair

Hispanic Health Fair- Volunteer

Smile of KY Selection Committee 